\title{
Effects of oyster population restoration strategies on phytoplankton biomass in Chesapeake Bay: a flexible modeling approach
}

\author{
Richard S. Fulford ${ }^{1,4, *}$, Denise L. Breitburg ${ }^{1}$, Roger I. E. Newell ${ }^{2}$, W. Michael Kemp ${ }^{2}$, \\ Mark Luckenbach ${ }^{3}$ \\ ${ }^{1}$ Smithsonian Environmental Research Center, 647 Contees Wharf Road, Edgewater, Maryland 21037, USA \\ ${ }^{2}$ Horn Point Laboratory, University of Maryland Center for Environmental Science, PO Box 775, Cambridge, \\ Maryland 21613, USA \\ ${ }^{3}$ Virginia Institute of Marine Science Eastern Shore Laboratory, PO Box 350, Wachapreague, Virginia 23480, USA \\ ${ }^{4}$ Present address: University of Southern Mississippi, Gulf Coast Research Laboratory, PO Box 7000, Ocean Springs, \\ Mississippi 39566-7000, USA
}

\begin{abstract}
Cultural eutrophication in estuaries and other coastal systems has increased over the last 50 yr. Some recently proposed strategies to reverse this trend have included the restoration of bivalve suspension feeders as an ecological tool for reducing phytoplankton biomass. The ecological benefits accruing from such bivalve restoration will be dependent on the characteristics of the estuary, as well as how restoration is implemented. We developed a filtration model to estimate the effect of bivalve restoration on the rate of phytoplankton removal over a range of spatial and temporal scales and used it to compare alternate restoration strategies for the eastern oyster Crassostrea virginica in Chesapeake Bay, USA. Model results suggested that currently accepted restoration goals for oysters in the bay are unlikely to result in significant bay-wide reductions in phytoplankton biomass. This is partially due to low current biomass targets for oyster restoration, but also important are several spatial and temporal mismatches between oyster and phytoplankton biomass that may limit the ecological benefit of oyster restoration. Our model did predict important increases in phytoplankton removal by oysters at the tributary scale, and this effect was dependent on where oyster restoration was achieved and whether restoration and management plans affected the size distribution of oysters. Our findings suggest that the ecological benefit of restoring bivalve populations are variable, and a comparative model analysis of restoration plans in particular systems can be highly beneficial to maximizing the benefit-to-cost ratio of restoration efforts intended to reduce the negative effects of cultural eutrophication.
\end{abstract}

KEY WORDS: Oysters $\cdot$ Ecosystem $\cdot$ Management $\cdot$ Filter-feeding $\cdot$ Restoration $\cdot$ Estuary

\section{INTRODUCTION}

Cultural eutrophication has steadily increased over the last $50 \mathrm{yr}$, resulting in declining water quality and shifts from benthic-dominated to pelagic-dominated primary production in many estuaries throughout the world (Nixon 1995, Cloern 2001, Kemp et al. 2005). Efforts to reduce or reverse this trend have generally focused on reducing the input of new nutrients and organic material to the system (Jordan et al. 2003, Fear et al. 2004, Neumann \& Schemewski 2005). In some of these same systems, biomass of bivalve suspension feeders was greatly reduced prior to major increases in anthropogenic nutrient loadings, primarily as a result of overharvesting (Mackenzie et al. 1997). Declines of many stocks continued throughout 
the 20th century as a consequence of multiple stressors, including fisheries exploitation, disease, and habitat degradation. Many studies have suggested that bivalve suspension feeders may serve as a means for reducing concentrations of phytoplankton and other suspended particulates and for restoring the ecosystem to one with higher rates of benthic primary production (Newell \& Ott 1998, Nakamura \& Kerciku 2000, Cressman et al. 2003). As a result, the restoration of benthic suspension-feeder biomass has been proffered as a potentially important way to supplement curbing nutrient inputs as a means to reverse cultural eutrophication (Officer et al. 1982, Newell et al. 2005).

Both reducing nutrient loading and the restoration of benthic suspension-feeder populations can decrease phytoplankton biomass in the water column and, in this respect, these can be considered complementary management strategies. However, just as alternate approaches for reducing point and non-point source nutrient inputs vary in efficacy, the water-quality benefits derived from increased biomass of benthic suspension feeders may depend on restoration strategies and characteristics of the specific target species and ecological system. These factors need to be examined to assess the benefits of benthic suspension-feeder restoration as a viable complement for other restoration actions.

Chesapeake Bay is the largest estuary in the United States, and represents a valuable reference system for assessing the role of benthic suspension feeders for improving water quality. Chesapeake Bay has suffered from a long history of cultural eutrophication, resulting in increased phytoplankton biomass (Kemp et al. 2005), decreased water clarity (Gallegos 2001), increases in the severity and extent of seasonal hypoxia (Breitburg 1990, Boicourt 1992, Hagy et al. 2004), and decreases in the biomass of submerged aquatic vegetation (Kemp et al. 1983, Orth \& Moore 1983, Orth et al. 2002). Chesapeake Bay has also been subjected to direct impacts on its living resources through overfishing and disease. In particular, the abundance of eastern oysters Crassostrea virginica has declined dramatically as a result of overharvesting, disease, and siltation of oyster reef habitat (Jordan et al. 2002).

Recognition of these problems has led to an extensive effort to reduce the delivery of nutrients into Chesapeake Bay (Correll et al. 1999, 2000, Jordan et al. 2003), as well as research and public interest in oyster population restoration (Brumbaugh et al. 2000, NRC 2004, Newell et al. 2005). Prior to commercial exploitation, the oyster population in Chesapeake Bay was at least 2 orders of magnitude higher than its present levels (Newell 1988, Jordan \& Coakley 2004).
The intense filtration activity associated with this large oyster population is thought to have made a major contribution to the control of phytoplankton abundance under historic conditions of nutrient and sediment delivery (Newell 1988, Newell \& Ott 1998). This removal of phytoplankton and suspended inorganic particles would have increased water clarity in the summer (Newell 2004, Newell \& Koch 2004). If these historical abundances of oysters were still present they may have made Chesapeake Bay more resilient to anthropogenic nutrient inputs (Newell et al. 2005). It is difficult, however, to predict the restorative role of a particular factor, such as an oyster biomass increase, in a system like Chesapeake Bay that has been affected by multiple anthropogenic stressors and is characterized by substantial temporal and spatial variation in factors that can influence the magnitude of benefit derived from restoration efforts.

Both mesocosm experiments (Olsson et al. 1992) and field data (Cloern 1982, Officer et al. 1982, Dame 1996, Souchu et al. 2001) from other systems suggest that increased biomass of suspension-feeding bivalves can reduce phytoplankton biomass and increase water clarity. Prins et al. (1998) did observe that bivalve feeding may actually increase phytoplankton production close to the oyster beds due to nutrient recycling and size-selective clearance efficiency. However, this observed increase in primary production may result from a localized concentration of excreted nutrients in the vicinity of the bivalve population that is outweighed by filtration effects at somewhat larger spatial scales (Newell et al. 2005).

The ability of a restored oyster population to remove large amounts of phytoplankton biomass from the water column will be influenced by seasonal patterns of oyster clearance rates, as well as phytoplankton biomass, production, and size-composition. Malone (1992) observed that 'seasonal imbalances' between phytoplankton production and consumption by grazers generate the seasonal peak in phytoplankton biomass in the spring, when grazing is lowest. In summer, high grazing controls biomass, but rapid nutrient recycling sustains maximum rates of phytoplankton production. Oysters typically achieve maximum filtration rates at times of maximum summer water temperatures (Newell \& Langdon 1996). As a result, increased oyster grazing pressure resulting from increased oyster biomass would be greatest during the summer, when grazing pressure from other suspension feeders is already high. Further, oyster particle retention is a function of cell size, with efficiency declining sharply for particles smaller than $2 \mu \mathrm{m}$ (i.e. picoplankton; Langdon \& Newell 1990). Under present-day eutrophic conditions in the bay, the relative biomass of picoplankton, which are largely unavailable to oysters, 
increases to around $20 \%$ of total phytoplankton biomass during the warmer summer months (Ray et al. 1989, Lacouture et al. 1990). The resulting seasonal matching between maximum oyster filtration and maximum relative biomass of small-celled phytoplankton may limit the effect of oyster filtration on phytoplankton biomass.

Established management plans for Chesapeake Bay call for a bay-wide 10-fold increase in oysters over the low abundances present in 1994 (Chesapeake 2000 agreement; www.chesapeakebay.net/c2k.htm). This restoration effort is designed to both improve water quality and provide a harvestable resource for the public oyster fishery. At present, it is unclear what gain in water quality will occur if this goal is achieved, or how the spatial pattern of restoration or the combination of restoration and harvest restrictions might contribute to improving water quality. In this analysis we take a relatively simple comparative approach, focusing on spatial and temporal aspects of estimated filtration for alternative oyster restoration strategies. We recognize that restoration trajectories are likely to be non-linear and difficult to predict for a complex ecosystem like Chesapeake Bay, which is simultaneously affected by multiple stressors (Suding et al. 2004, Kemp et al. 2005). We focus on oysters because they are a restoration priority for Chesapeake Bay and because the relative ecological value of different oyster restoration strategies has not received extensive attention. Within this comparative framework we then draw inferences about how restoration of bivalve suspension feeders in general may be designed to achieve maximum ecological benefit. Our goal was to provide both insight into the potential benefits increased oyster biomass might yield and to develop a flexible computational tool for exploring alternative management strategies.

Our specific objectives were: (1) to estimate seasonal and spatial patterns in oyster removal rates for phytoplankton under present conditions in Chesapeake Bay; (2) to examine the probable change in the impact of oysters on phytoplankton abundance resulting from various restoration scenarios; and (3) to interpret these data with respect to maximizing the ecological benefits of oyster restoration on phytoplankton removal. Phytoplankton removal is used here as an index of effect for comparative purposes. It is widely recognized that water filtration is but one of a suite of ecological services provided by benthic suspension feeders. We do not consider here other ecological benefits provided by oysters, such as altering processes of inorganic nutrient regeneration (Newell et al. 2005) and providing habitat for fish and other invertebrate species (Harding \& Mann 1999, Breitburg et al. 2000).

\section{MATERIALS AND METHODS}

Data and approach. We estimated the trophic effects of oysters at various scales within a spatially and temporally explicit oyster filtration model that estimated phytoplankton biomass removed daily by oysters. Our calculations expand on the approach of Newell (1988) by taking into account the spatial and temporal distribution of phytoplankton biomass and size distribution; spatial and temporal patterns in temperature, salinity, dissolved oxygen, and seston concentration as they affect oyster filtration; and spatial patterns in current oyster biomass. Input data were organized by Bay Monitoring Segment (hereafter 'segment'; EPA Chesapeake Bay Monitoring Program) so that oysters in each of the 36 segments (Table 1; www.chesapeakebay.net/ pubs/maps/1998-002.pdf) that are estimated to currently contain oysters could be treated as spatially discrete regions, with no transfer of materials between adjacent segments. This assumption means that our analysis cannot address the impacts of an increase in oyster biomass in one region (e.g. a particular tributary) on phytoplankton biomass in other areas (e.g. the mainstem bay near the tributary mouth). We address the implications of this assumption in the 'Discussion'. Although some of the major rivers flowing into Chesapeake Bay can be considered estuaries in their own right, we refer to all systems flowing directly or indirectly into Chesapeake Bay as tributaries to distinguish them from the mainstem bay.

We estimated daily oyster-specific clearance rates $\left(\mathrm{m}^{3} \mathrm{~kg}^{-1} \mathrm{C} \mathrm{d}^{-1}\right)$ within each segment for each month and converted the specific clearance rate to the total water cleared per day $\left(\mathrm{m}^{3} \mathrm{~d}^{-1}\right)$ by multiplying the specific rate by the total oyster biomass in each segment. We defined clearance rate for modeling purposes as the total volume of water cleared of suspended particles per day by a given biomass of oysters. In most model scenarios we assumed a homogenous oyster population comprised of individuals of $1 \mathrm{~g}$ dry weight (DW; shell height $7.6 \mathrm{~cm}, 0.5 \mathrm{~g} \mathrm{C}$; see Table 2 for exceptions). Oysters filter particles larger than $4 \mu \mathrm{m}$ at near $100 \%$ efficiency (Langdon \& Newell 1990), but for smaller sized particles clearance rates were adjusted by a filtration efficiency term described below.

We estimated daily phytoplankton removal by oysters by multiplying total daily clearance rate estimates for each segment and month by estimates of available phytoplankton biomass per cubic meter in each segment and month. We converted this estimate to the proportion of phytoplankton removed daily by oysters by dividing total phytoplankton biomass removed by total phytoplankton biomass in a respective segment and month. A bay-wide average daily proportion of phytoplankton removed in each month was calculated 
Table 1. Physical characteristics and oyster biomass estimates by Bay Monitoring Segment (BMS). Water volume is given for the total segment and for the surface-mixed layer (SML) only. The annual mean is given for water temperature (Temp.), dissolved oxygen concentration (DO), salinity, and seston concentration (TSS)

\begin{tabular}{|c|c|c|c|c|c|c|c|}
\hline BMS name & $\begin{array}{l}\text { Total volume } \\
\qquad\left(10^{6} \mathrm{~m}^{3}\right)\end{array}$ & $\begin{array}{l}\text { SML volume } \\
\quad\left(10^{6} \mathrm{~m}^{3}\right)\end{array}$ & $\begin{array}{l}\text { Temp. } \\
\left({ }^{\circ} \mathrm{C}\right)\end{array}$ & $\mathrm{DO}$ & $\begin{array}{l}\text { Salinity } \\
\left(\mathrm{mg} \mathrm{l}^{-1}\right)\end{array}$ & $\begin{array}{c}\text { TSS } \\
\left(\mathrm{mg} \mathrm{l}^{-1}\right)\end{array}$ & $\begin{array}{l}\text { Oyster biomass } \\
\quad\left(10^{3} \mathrm{~kg} \mathrm{C}\right)\end{array}$ \\
\hline BIGMH & 43.6 & 25.9 & 15.72 & 8.97 & 15.61 & 16.60 & 4.62 \\
\hline CB2OH & 1240.0 & 1130.0 & 14.31 & 8.84 & 4.53 & 19.15 & 2.75 \\
\hline СВ3МH & 2390.0 & 1860.0 & 14.61 & 8.19 & 10.81 & 11.58 & 22.2 \\
\hline CB4MH & 9240.0 & 7190.0 & 14.72 & 7.75 & 14.17 & 7.35 & 38.3 \\
\hline CB5MH & 15400.0 & 12000.0 & 15.08 & 8.27 & 16.73 & 9.13 & 89.7 \\
\hline CB6PH & 6500.0 & 4170.0 & 15.36 & 8.94 & 18.86 & 15.42 & 93.7 \\
\hline CB7PH & 13500.0 & 8670.0 & 15.06 & 8.64 & 21.81 & 21.23 & 0.28 \\
\hline СНОМН1 & 945.0 & 562.0 & 14.73 & 9.32 & 12.73 & 12.46 & 29.9 \\
\hline СНОМН2 & 267.0 & 159.0 & 15.09 & 8.58 & 10.43 & 17.55 & 5.65 \\
\hline $\mathrm{CHOOH}$ & 45.1 & 29.6 & 15.90 & 8.41 & 0.58 & 53.54 & 0.0296 \\
\hline CHSMH & 455.0 & 271.0 & 14.51 & 8.78 & 10.21 & 13.51 & 7.76 \\
\hline CRRMH & 65.7 & 39.1 & 16.17 & 8.28 & 14.88 & 7.23 & 36.4 \\
\hline EASMH & 997.0 & 593.0 & 14.63 & 8.41 & 12.58 & 10.36 & 18.4 \\
\hline FSBMH & 143.0 & 85.0 & 15.15 & 8.87 & 13.26 & 33.03 & 9.46 \\
\hline HNGMH & 186.0 & 110.0 & 15.15 & 8.87 & 13.26 & 33.03 & 15.3 \\
\hline JMSMH & 977.0 & 581.0 & 16.26 & 8.34 & 14.82 & 26.63 & 724.0 \\
\hline LCHMH & 208.0 & 124.0 & 14.29 & 8.01 & 13.76 & 14.40 & 4.33 \\
\hline MAGMH & 76.5 & 45.5 & 14.96 & 8.57 & 8.74 & 10.01 & 0.997 \\
\hline MANMH & 89.5 & 53.2 & 15.61 & 8.76 & 14.07 & 26.60 & 10.2 \\
\hline МOBРН & 1340.0 & 944.0 & 15.85 & 8.88 & 20.07 & 17.29 & 3.31 \\
\hline NANMH & 97.3 & 57.8 & 15.57 & 8.59 & 8.32 & 59.86 & 0.502 \\
\hline PATMH & 452.0 & 268.0 & 15.06 & 8.02 & 9.53 & 11.72 & 0.0211 \\
\hline PAXMH & 561.0 & 334.0 & 15.17 & 8.13 & 12.65 & 10.85 & 7.23 \\
\hline PAXOH & 27.2 & 17.8 & 15.87 & 8.18 & 10.37 & 43.56 & 0.0084 \\
\hline PIAMH & 201.0 & 120.0 & 15.74 & 9.68 & 16.25 & 11.94 & 121.0 \\
\hline POCMH & 355.0 & 211.0 & 15.53 & 9.22 & 17.12 & 24.36 & 3.97 \\
\hline POCOH & 18.0 & 11.8 & 15.53 & 9.22 & 2.28 & 24.36 & 0.0047 \\
\hline РОTMH & 5790.0 & 3440.0 & 15.53 & 8.54 & 12.55 & 13.85 & 19.5 \\
\hline РОТОН & 852.0 & 559.0 & 15.53 & 8.75 & 2.79 & 42.49 & 0.707 \\
\hline RHDMH & 20.3 & 12.1 & 15.82 & 9.29 & 10.11 & 14.15 & 0.128 \\
\hline RPPMH & 1480.0 & 881.0 & 15.67 & 8.48 & 14.23 & 25.24 & 90.1 \\
\hline SEVMH & 113.0 & 67.5 & 15.06 & 8.09 & 10.18 & 12.66 & 1.82 \\
\hline SOUMH & 67.0 & 39.8 & 15.32 & 7.31 & 10.38 & 11.36 & 2.18 \\
\hline TANMH & 4020.0 & 2390.0 & 15.19 & 8.31 & 16.16 & 22.05 & 87.1 \\
\hline WICMH & 56.4 & 33.5 & 15.88 & 7.99 & 7.73 & 33.99 & 0.811 \\
\hline WSTMH & 20.4 & 12.1 & 15.21 & 9.02 & 10.52 & 16.10 & 0.562 \\
\hline
\end{tabular}

by taking the unweighted mean proportion of phytoplankton removed daily across all segments. This mean can be thought of as the mean local effect of oyster filtration on phytoplankton biomass across all segments, and provides a number that can be compared to phytoplankton growth rates in order to estimate net oyster effect on phytoplankton density. This unweighted mean was calculated separately for the mainstem of the bay and for the tributary segments combined in order to minimize segment size bias. We calculated an annual average of the proportion of phytoplankton removed daily by taking the mean of the 12 monthly values within each segment. A baywide annual average was estimated by taking the unweighted mean of the annual averages for the mainstem of the bay and for the tributaries as described above for the monthly bay-wide average. We also com- puted a segment volume-weighted mean phytoplankton removal, but this measure was relatively insensitive to the restoration strategies tested because of the influence of several bay segments with large water volumes and low oyster biomasses.

Phytoplankton biomass estimates. Total phytoplankton biomass in each segment was based on esti-

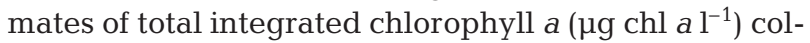
lected at specific monitoring stations in each segment and interpolated to produce an estimate of total chl a for an entire segment (D. Jasinski, EPA Chesapeake Bay Program, unpubl. data). The estimate of total chl a was converted to kilograms of carbon assuming a carbon:chl a ratio of 40 . The ratio of carbon to chl a will vary depending on changes in light, nutrient concentration, and temperature (Cloern et al. 1995). The value used in our model is the geometric mean 
carbon:chl a ratio used in a previous model analysis to estimate the amount of phytoplankton carbon in Chesapeake Bay (Gallegos 2001). Analysis of phytoplankton biomass was limited to segments that contain oysters, which includes polyhaline, mesohaline, and lower oligohaline segments. Therefore, results and analysis of phytoplankton data do not include upper oligohaline or tidal fresh segments.

Total phytoplankton biomass was divided into 3 size classes $(<2 \mu \mathrm{m}, 2$ to $4 \mu \mathrm{m},>4 \mu \mathrm{m})$. These size classes, used for phytoplankton, were based on published estimates of oyster clearance efficiency as a function of phytoplankton cell size (Langdon \& Newell 1990). Allocating phytoplankton to size classes allowed us to examine the relationship between oyster feeding activity and seasonal patterns in the size composition of phytoplankton biomass. The estimate of size-specific phytoplankton biomass in each segment was reduced to account for phytoplankton biomass estimated to be beneath the pycnocline. Oysters do not reside in the deep waters below the pycnocline, and we assumed that the surface layer, defined as the volume of water between the pycnocline and the surface, is well mixed horizontally, so oysters have access to all phytoplankton biomass in the surface layer. This assumption may result in an overestimate of oyster access to phytoplankton, particularly in the mainstem bay, and is considered in the 'Discussion'.

Total phytoplankton biomass was allocated to size class and adjusted to account only for biomass above the pycnocline, based on estimates of relative abundance calculated from mean cell count data collected in each segment and month as a part of the Bay Monitoring Program (1986 to 2001; www.chesapeakebay. net/data/index.htm). Mean cell count data (no. $\mathrm{l}^{-1}$ ) were converted to biomass $\left(\mathrm{g} \mathrm{C}^{-1}\right)$ with a conversion value (pg C cell-1) specific to phytoplankton taxonomic groups, provided by the Maryland principal investigator of the phytoplankton monitoring program and used by the Chesapeake Bay Program (R. Lacouture, Morgan State University Estuarine Research Center, EPA Chesapeake Bay Program, unpubl. data). These biomass estimates were then converted to the proportion of phytoplankton biomass in each size class above the pycnocline by dividing biomass from cell counts in each size class above the pycnocline by total biomass from cell counts for the whole water column. These proportions were then used to allocate total phytoplankton biomass from chl a data into the respective bins (above vs. below the pycnocline; size class). Phytoplankton relative abundance by size and vertical location were calculated separately for each segment and month.

Cell count data for picoplankton were available only for a subset of the segments. Mean picoplankton abun- dance was calculated by month and salinity zone and used to estimate picoplankton relative biomass in segments where no picoplankton data were available. The biomass conversion (pg C cell-1) for picoplankton was set at a nominal value of $0.2 \mathrm{pg} \mathrm{C} \mathrm{cell}^{-1}$ based on an observed mean cell diameter of $1 \mu \mathrm{m}$ (R. Lacouture, Morgan State University Estuarine Research Center \& H. Marshall, Old Dominion University, pers. comm.).

Oyster biomass estimates. Estimates of oyster biomass for each segment were based on surveys conducted in Virginia sections of the bay by the Virginia Institute of Marine Sciences and in Maryland sections of the bay by the Maryland Department of Natural Resources (Chesapeake Bay Oyster Population Estimation Project, www.vims.edu/mollusc/cbope/index. $\mathrm{htm}$ ). Data from the Virginia portion of the bay were based on patent tong surveys collected from 1998 to 2002 (Southworth et al. 2005). Data for the Maryland portion of the bay were based on the total recent biomass estimated by Jordan et al. (2002) and historical records of spatial distributions (Yates 1911). Data from both surveys were compiled and made available for use in our model by the Army Corps of Engineers Water Quality Modeling Group (Cerco \& Noel 2005). The variability of these biomass estimates is quite high (coefficient of variation $>100 \%$ ). However, these data are the best available and provide a viable starting point for an examination of oyster restoration. Oyster biomass was expressed as total oyster tissue $(\mathrm{kg} \mathrm{C})$ in each segment, and was converted to the equivalent number of $1 \mathrm{~g}$ DW oysters. Jordan et al. (2002) reported that in Maryland mean individual oyster weight was $1.18 \mathrm{~g} \mathrm{DW}$, and the mean ranged from 0.82 to $1.42 \mathrm{~g}$ DW across sites.

Oyster clearance model. Oyster clearance rate was estimated in the model based on 4 environmental variables measured by the EPA Chesapeake Bay Monitoring Program: water temperature, salinity, seston concentration (TSS), and dissolved oxygen (DO) concentration. Data used were 10 yr means (1991 to 2001) for each month in each segment. Oyster clearance rate, defined as the volume of water swept clear of particles, was calculated with functions based on existing knowledge of oyster physiology (Newell \& Langdon 1996, Shumway 1996).

Daily maximum oyster clearance rate $\left(\mathrm{CR}_{\max } \mathrm{m}^{3} \mathrm{~g}^{-1}\right.$ oyster $\mathrm{C} \mathrm{d}^{-1}$ ) was calculated based on mean monthly water temperature (Fig. 1A, Cerco \& Noel 2005):

$$
C R_{\max }=0.55 \times \mathrm{e}^{\left(-0.015(T-27)^{2}\right)}
$$

where $T$ is mean water temperature $\left({ }^{\circ} \mathrm{C}\right)$. Maximum oyster clearance rate reported by Newell \& Langdon (1996) was $0.55 \mathrm{~m}^{3} \mathrm{~g}^{-1} \mathrm{C} \mathrm{d}^{-1}$ and occurred at a temperature of $27^{\circ} \mathrm{C}$. The temperature-based maximum clear- 
A
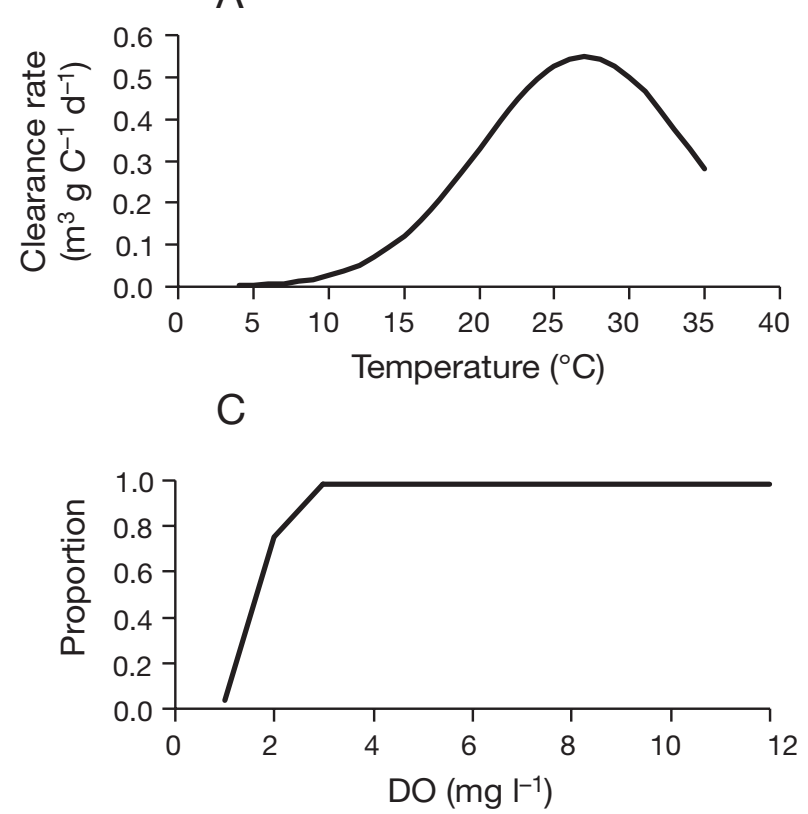

B
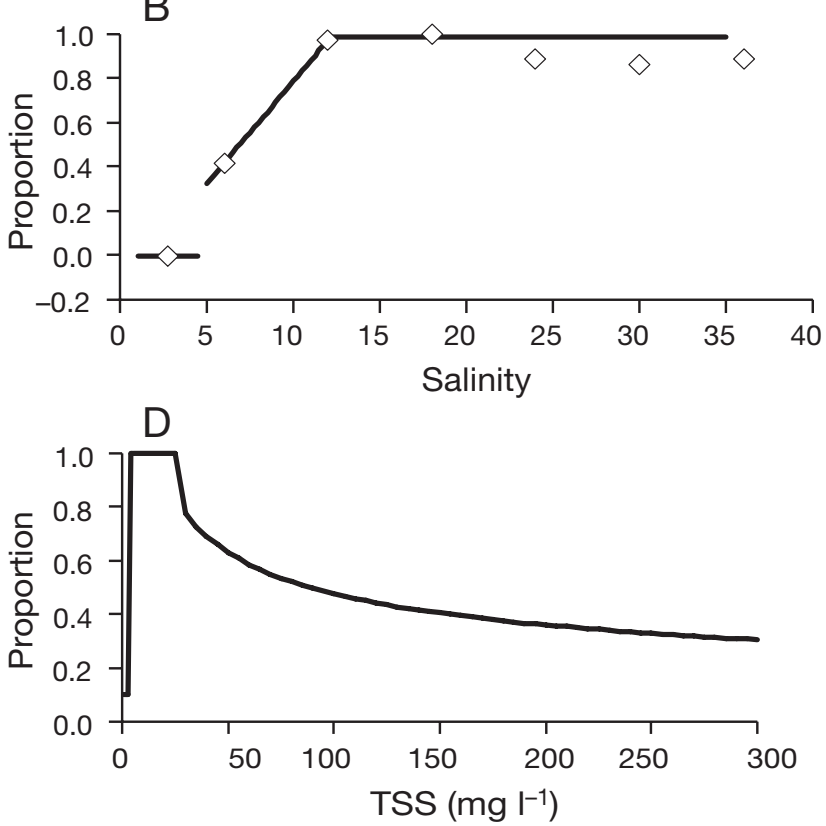

Fig. 1. Relationship between oyster clearance rate and: (A) mean water temperature; (B) salinity; (C) dissolved oxygen (DO), and (D) seston concentration (TSS). Relationships for salinity, DO, and TSS represent a proportion of the temperature-mediated maximum clearance rate. Functions used in the model are described by solid lines and data used to develop the function for salinity are provided for justification of the piecewise linear approach. The $x$-axis in Panel B crosses the $y$-axis at -0.2 to improve visibility of the function below a salinity of 5

ance rate was calculated in the model, converted to cubic meters per kilogram $\mathrm{C}$ per day and then adjusted for non-optimal conditions of the other 3 physical variables salinity, TSS, and DO:

$$
\mathrm{CR}=\mathrm{CR}_{\max } \times f(\text { salinity }) \times f(\mathrm{TSS}) \times f(\mathrm{DO})
$$

via multiplication by the respective coefficients.

Maximum clearance rate was adjusted for mean monthly salinity in a given segment using a discrete set of rules based on laboratory observations of oyster clearance across a salinity range (R. I. E. Newell unpubl. data; Fig. 1B). Oyster clearance has been observed to cease at salinities $<5$. Further, oyster clearance rate has been observed to be unaffected by salinities $>12$. In a given segment, if mean monthly salinity was $<5$ then oyster clearance rate was zero in the model for that segment in that month. If mean monthly salinity was $>12$, oysters in the model cleared water at their temperature-based maximum rate in that month. In segments and months with a mean salinity between 5 and 12, oyster clearance was adjusted based on a linear function:

$$
f(\text { salinity })=(0.0926 \times S)-0.139
$$

where $S$ is the segment- and month-specific mean salinity and $f$ (salinity) is the proportion of maximum clearance rate realized at the specified salinity. Maximum clearance rate was adjusted for mean DO con- centration $\left(\mathrm{mg} \mathrm{l}^{-1}\right)$ in a given segment with a logistic function relating mean DO concentration in a given segment and month to the critical DO concentrations for oyster feeding activity (Fig. 1C):

$$
f(\mathrm{DO})=\frac{1}{1+\exp \left(1.1 \times \frac{\mathrm{DO}_{\mathrm{hx}}-\mathrm{DO}}{\mathrm{DO}_{\mathrm{hx}}-\mathrm{DO}_{\mathrm{qx}}}\right)}
$$

where $\mathrm{DO}_{\mathrm{hx}}\left(1.75 \mathrm{mg} \mathrm{l}^{-1}\right)$ and $\mathrm{DO}_{\mathrm{qx}}\left(1.5 \mathrm{mg} \mathrm{l}^{-1}\right)$ are the DO concentrations at which the oyster clearance rate is 50 and $25 \%$ of its maximum value, respectively. These equations were developed from generalized responses of bivalve mollusks to declining oxygen tension (Bayne 1971a,b).

Oysters do not feed actively at low seston levels, but clearance rates increase rapidly as seston concentrations rise above $4 \mathrm{mg} \mathrm{l}^{-1}$ (Newell \& Langdon 1996), and for this response we used a step function (Fig. 1D). Oyster clearance rate was $10 \%$ of the temperatureadjusted maximum rate at seston concentrations $<4 \mathrm{mg} \mathrm{l}^{-1}$, increased to $100 \%$ of the maximum rate at seston concentrations between 4 and $25 \mathrm{mg} \mathrm{l}^{-1}$, and decreased as seston concentrations increased to $>25 \mathrm{mg} \mathrm{l}^{-1}$ (Loosanoff 1962, Newell \& Langdon 1996). Loosanoff (1962) reported that oysters can feed at seston concentrations as high as $1000 \mathrm{mg} \mathrm{l}^{-1}$. We modeled clearance rates at higher seston concentrations as a power function derived from the data relating oys- 
ter clearance rate to seston concentrations $>25 \mathrm{mg} \mathrm{l}^{-1}$ (Fig. 1D):

$$
f(\mathrm{TSS})=10.364 \times \log (\mathrm{TSS})^{-2.0477}
$$

where $\log (\mathrm{TSS})$ is the natural logarithm of seston concentration for a given segment. This function describes a decrease in oyster clearance rate that is initially rapid, but slows for seston concentrations $>100 \mathrm{mg} \mathrm{l}^{-1}$. Oyster clearance rate was predicted to be about $43 \%$ of the temperature-adjusted maximum rate at a seston concentration of $100 \mathrm{mg} \mathrm{l}^{-1}$.

Oyster clearance rates in each segment and month were calculated based on mean values for the 4 physical variables. The specific clearance estimate $\left(\mathrm{m}^{3} \mathrm{~kg}^{-1}\right.$ oyster $\mathrm{C} \mathrm{d}^{-1}$ ) was multiplied by oyster biomass ( $\mathrm{kg} \mathrm{C}$ ) in a segment to estimate total volume cleared daily $\left(\mathrm{m}^{3} \mathrm{~d}^{-1}\right)$. Total volume cleared was converted to phytoplankton removed daily ( $\mathrm{kg}$ phytoplankton $\mathrm{C} \mathrm{d}^{-1}$ ) by multiplying the total volume cleared in each segment and month by the total available phytoplankton biomass per unit volume in each segment and month $\left(\mathrm{kg} \mathrm{C} \mathrm{m}^{-3}\right)$. Total phytoplankton removed daily was then converted to proportion of total phytoplankton biomass removed daily by dividing the biomass removed by the total phytoplankton biomass in the respective segment and month.

Model scenarios and sensitivity analyses. We used the model to estimate the daily removal of phytoplankton by oysters in each segment based on the mean data described above for current oyster and phytoplankton biomass and under a range of scenarios for increasing oyster biomass and altering oyster biomass distribution in Chesapeake Bay (hereafter 'restoration scenarios'; Table 2). The management oyster restoration target for the bay is a 10 -fold increase over the low values in 1994. We used the model to predict the change in daily phytoplankton removal by oysters resulting from a 10-fold increase in oyster biomass with current oyster distribution (Fig. 2A). In addition, we used the model to predict change in phytoplankton removal resulting from a 10-fold increase in oyster biomass combined with a targeted redistribution focused largely in 3 local areas (Tangier Sound, Choptank River, and the Rappahannock River; Fig. 2B). The local areas chosen for the 'redistribution' scenario are areas with historically high oyster abundances.

The final 2 scenarios, designated as limited harvest scenarios, were designed to test the effects of oyster size distribution on phytoplankton removal. Oyster restoration strategies are often linked to fisheries regulations designed to restrict removal of oysters, at least for some period of time. The way in which fisheries regulations are implemented can simultaneously affect oyster biomass, numbers, and sizes. Our intention was not to simulate detailed size structure of oyster populations, but rather to explore the consequences of an increase in mean oyster size by using 2 simple scenarios in which the abundance of currently harvestable oysters $>7.6 \mathrm{~cm}$ shell height would increase. Maximum oyster clearance rate is a function of oyster size (Newell \& Langdon 1996). Larger individuals have higher clearance rates on a per individ-

Table 2. Summary of the oyster restoration scenarios being compared, based on results of the seasonal oyster filtration model. The 3 tributaries receiving most of the increase in oyster biomass under the 'redistribution' scenario were Tangier Sound, the Choptank River, and the Rappahannock River. Changes in individual oyster size were treated in the model as changes in the maximum clearance rate (see 'Materials and methods' for details) and are given here as grams of dry weight (DW) to aid interpretation

\begin{tabular}{|c|c|c|c|}
\hline $\begin{array}{l}\text { Restoration } \\
\text { scenarios }\end{array}$ & $\begin{array}{l}\Delta \text { Oyster } \\
\text { biomass }\end{array}$ & $\begin{array}{l}\text { Individual } \\
\text { oyster size }\end{array}$ & Details \\
\hline Current biomass & $\mathrm{n} / \mathrm{a}$ & $1 \mathrm{~g} \mathrm{DW}$ & Current biomass and distribution \\
\hline In place & $\begin{array}{l}10 \times \\
25 \times\end{array}$ & $1 \mathrm{~g} \mathrm{DW}$ & Oyster restoration with current distribution \\
\hline Redistribution & $\begin{array}{l}10 \times \\
25 \times\end{array}$ & $1 \mathrm{~g} \mathrm{DW}$ & Oyster restoration with redistribution focused in 3 tributaries \\
\hline $\begin{array}{l}\text { Limited harvest with } \\
\text { redistribution } \\
\text { (biomass target) }\end{array}$ & $\begin{array}{l}10 \times \\
25 \times\end{array}$ & $\begin{array}{l}50 / 501 \mathrm{~g} \text { and } \\
3 \mathrm{~g} \mathrm{DW}\end{array}$ & $\begin{array}{l}\text { Oyster restoration with redistribution and limited harvest with total } \\
\text { within-segment biomass the same as in the redistribution scenario }\end{array}$ \\
\hline $\begin{array}{l}\text { Limited harvest with } \\
\text { redistribution } \\
\text { (numerical target) }\end{array}$ & $\begin{array}{l}20 \times \\
50 \times\end{array}$ & $\begin{array}{l}50 / 501 \mathrm{~g} \text { and } \\
3 \mathrm{~g} \mathrm{DW}\end{array}$ & $\begin{array}{l}\text { Oyster restoration with redistribution and limited harvest with number } \\
\text { of individual oysters per segment (based on } 0.5 \mathrm{~g} \mathrm{C} \text { oyster }^{-1} \text { ) the same } \\
\text { as in the redistribution scenario }\end{array}$ \\
\hline Historic biomass & $100 \times$ & $1 \mathrm{~g} \mathrm{DW}$ & Oyster restoration to biomass levels prior to 1870 \\
\hline
\end{tabular}



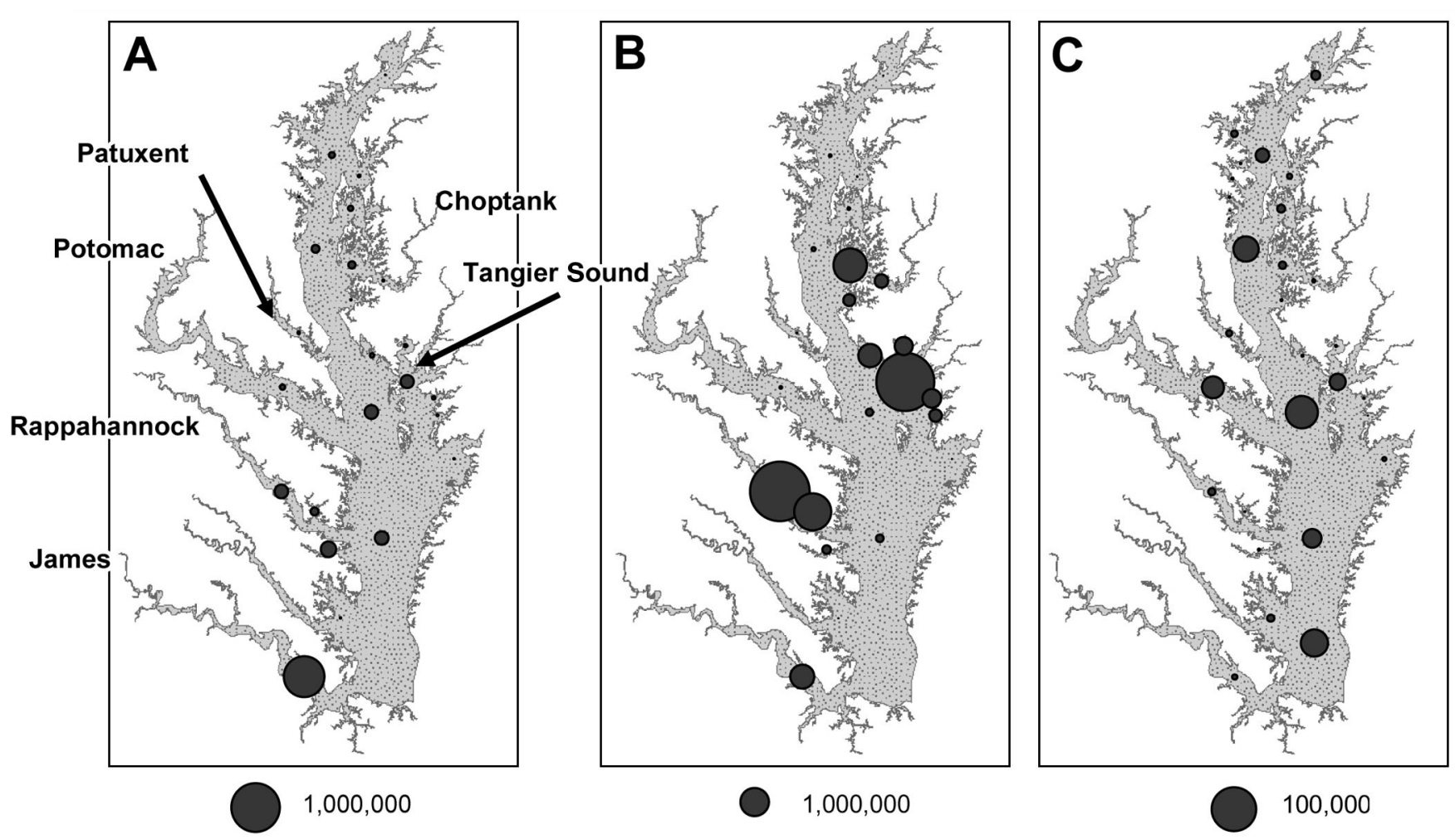

Fig. 2. (A) Current oyster biomass distribution in kg oyster carbon; (B) oyster biomass distribution for the 'redistribution' model scenario in $\mathrm{kg}$ oyster carbon, and (C) in mean phytoplankton biomass (tonnes phytoplankton carbon), in each bay monitoring segment. Points on the figure represent the integrated biomass for the entire segment rather than data from a particular monitoring station. Locations of points on the figure within a particular segment are arbitrary. Major tributaries are labeled in

Panel A for reference. See Table 1 for details on individual segments

ual basis, but the allometric exponent is less than unity, and larger individuals have lower clearance rates per unit biomass.

These 'limited harvest' oyster populations were assumed to have the same spatial distributions as oysters in the 'redistribution' scenario, but were comprised of a mixture of $0.5 \mathrm{~g} \mathrm{C}(1 \mathrm{~g} \mathrm{DW})$ and $1.5 \mathrm{~g} \mathrm{C}$ (3 g DW) oysters. This altered size distribution is based on the assumption that a portion of the oyster population achieves an additional year of growth prior to harvest. 'Limited harvest/biomass-target' simulations were assigned the same total biomass as used in the redistribution simulations (i.e. current biomass and 10- and 25-fold current biomass), with biomass evenly split between $1 \mathrm{~g}$ (50\% total biomass) and $3 \mathrm{~g}$ DW (50\% total biomass) individuals. The limited harvest/biomass-target scenario simulates a management strategy that utilizes harvest restrictions to meet biomass restoration goals. In addition, a limited harvest/ numerical-target scenario was developed to simulate a management strategy that utilizes harvest restrictions to meet a goal of increasing oyster numbers. Simulations of this scenario were assigned the same number of oysters as in the redistribution simulations, with oysters evenly split between $1 \mathrm{~g}$ (50\% total number) and $3 \mathrm{~g}$ DW (50\% total number) individuals. The limited harvest/numerical-target scenario results in a 25/75 split in biomass between 1 and 3 g DW individuals and a doubling of total biomass relative to other comparable (i.e. current conditions, 10× and 25×) simulations. Together, the 2 limited harvest scenarios bracket a range of population responses to an increase in size distribution. The maximum filtration rate for the limited harvest populations $\left(\mathrm{CR}_{\mathrm{pop}}\right)$ was 0.48 or $0.44 \mathrm{~m}^{3} \mathrm{~g}^{-1}$ oyster $\mathrm{C} \mathrm{d}^{-1}$ for the biomass target and numerical target scenarios, respectively. The different $\mathrm{CR}_{\text {pop }}$ values are based on the functions:

$$
\begin{aligned}
& \mathrm{CR}_{\text {pop }}=\left(\mathrm{CR}^{*}{ }_{\max (1)} \times P_{1}\right)+\left(\mathrm{CR}^{*}{ }_{\max (3)} \times P_{3}\right) \\
& \mathrm{CR}^{*}{ }_{\max (i)}=0.55(W)^{-0.28}
\end{aligned}
$$

where $\mathrm{CR}^{*}{ }_{\max (i)}$ is the biomass-dependent maximum clearance rate of an oyster weighing $i \mathrm{~g} \mathrm{DW}, P_{i}$ is the proportion of total population biomass comprised of $i \mathrm{~g}$ DW oysters, and $W$ is individual oyster biomass (g DW) (Newell \& Langdon 1996).

We also compared model estimates of the ecological effect of a 10-fold increase in oyster biomass to a 
25-fold increase in oyster biomass for all restoration scenarios described above, and to the estimated effect of oysters at the 100-fold present day biomass levels estimated to be present in the bay prior to 1870 (Newell 1988). We included data on a 25- and 100-fold increase in oyster biomass to provide a useful range of values for comparison. The results from each restoration scenario were compared to estimates of phytoplankton maximum growth rate on an annual basis and by month as a measure of the effect of oyster filtration on phytoplankton concentration.

Model sensitivity to our estimate of picoplankton biomass was tested because of uncertainty in temporal and spatial variation in mean cell size of cells $<2 \mu \mathrm{m}$ in diameter within Chesapeake Bay ( $R$. Lacouture \& H. Marshall pers. comm.) and because these $<2 \mu \mathrm{m}$ cells are largely unavailable to oysters due to low clearance efficiency (Langdon \& Newell 1990, Newell \& Langdon 1996). Model output was generated at 3 levels of picoplankton relative biomass (low, medium, and high), corresponding to mean cell diameters of 0.8 , 1 , and $2 \mu \mathrm{m}$ and biomass conversions of $0.11,0.2$, and $0.4 \mathrm{pg} \mathrm{cell}^{-1}$, respectively. The medium relative biomass level is the nominal model input value based on observations of mean cell size (R. Lacouture pers. comm.). Retention efficiency was estimated as $5 \%$ for mean cell sizes of 0.8 and $1 \mu \mathrm{m}(\equiv 0.11$ and $0.2 \mathrm{pg}$ cell $^{-1}$ ), and increased to $50 \%$ for a mean cell size of $2 \mu \mathrm{m}\left(\equiv 0.4 \mathrm{pg} \mathrm{cell}^{-1}\right)$.

\section{RESULTS}

\section{Spatial patterns}

Recent studies (Jordan et al. 2002, Southworth et al. 2005) indicate that Chesapeake Bay eastern oyster populations are $\sim 1 \%$ of the pre-exploitation levels estimated by Newell (1988). The spatial distribution of current oyster biomass is strongly skewed, with $49 \%$ of current biomass located in the mesohaline section of the James River (Fig. 2A). The mesohaline sections of the Rappahannock River, Tangier Sound, and the mainstem waters in Virginia each contain $>6 \%$ of the total oyster biomass, respectively. No other segment contains $>3 \%$ of the oyster biomass at present (Cerco \& Noel 2005).

Under average annual climatic conditions, $63 \%$ of the phytoplankton biomass is currently concentrated in the mesohaline mainstem bay (Fig. 2C). The mesohaline sections of the Potomac River, as well as the mesohaline section of Tangier Sound, contain 5.4 and $3.1 \%$ of the total phytoplankton biomass, respectively. No other segment contains $>2 \%$ of the total phytoplankton biomass.
We estimated that, on an annual basis, oysters currently remove $6.94 \times 10^{4} \mathrm{~kg}$ phytoplankton $\mathrm{C} \mathrm{d}^{-1}$, which represents $0.03 \%$ of total available phytoplankton carbon in Chesapeake Bay based on a volume-weighted average across all segments. Mean daily phytoplankton removal was highest in July $\left(3.4 \% \mathrm{~d}^{-1}\right)$ and lowest in February $\left(0.001 \% \mathrm{~d}^{-1}\right)$.

In the James River, mean daily phytoplankton removal by oysters was $3.2 \times 10^{4} \mathrm{~kg} \mathrm{C} \mathrm{d}^{-1}(13.5 \%)$ annually and peaked in July at $11.5 \times 10^{4} \mathrm{~kg} \mathrm{C} \mathrm{d}^{-1}(36.7 \%$; Fig. 3). Oyster populations in only 2 other segments had a mean daily clearance estimate $>2 \%$ phytoplankton $\mathrm{C} \mathrm{d}^{-1}$ : the mesohaline sections of the Corrotoman River $\left(11.1 \% \mathrm{~d}^{-1}\right)$, which is a tributary of the Rappahannock River; and the Piankatank River $\left(10.8 \% \mathrm{~d}^{-1}\right)$, located just to the south of the mouth of the Rappahannock River in Virginia.

Spatial patterns in the daily oyster clearance of phytoplankton were largely controlled by mean salinity and oyster biomass (Fig. 3). Annual averages in oligohaline areas that contain oysters were affected by months with oyster filtration rates at or near zero, because of low salinity. Highest annual filtration rates occurred in segments with highest oyster biomass and mean salinity $>10$ in all months.

\section{Temporal patterns}

Oyster daily clearance rate exhibited a distinct seasonal pattern predominantly mediated by mean water temperature (Fig. 4). Removal of phytoplankton by oysters was lowest during the winter months (December through March) and highest during the summer (June through September), when mean water temperature was highest. Daily oyster clearance rate began to rise rapidly in response to the seasonal temperature increase in May, but in most segments, including the James River, high oyster clearance rates did not occur until well after the spring peak in phytoplankton biomass, which occurred in March and April.

Phytoplankton size distribution also followed a distinct seasonal pattern (Fig. 5A). Phytoplankton $\leq 2 \mu \mathrm{m}$ in diameter (picoplankton) comprised a minor portion of total phytoplankton biomass from November through April. Relative abundance of picoplankton rose rapidly in May and peaked in August at an average of $22 \%$ of the total phytoplankton biomass in mesohaline segments for which data were available. This trend in the abundance of picoplankton follows an inverse pattern of the seasonal increase in oyster clearance rate and reduces the proportion of phytoplankton available to oysters during the season of peak oyster filtration (Fig. 5B). 

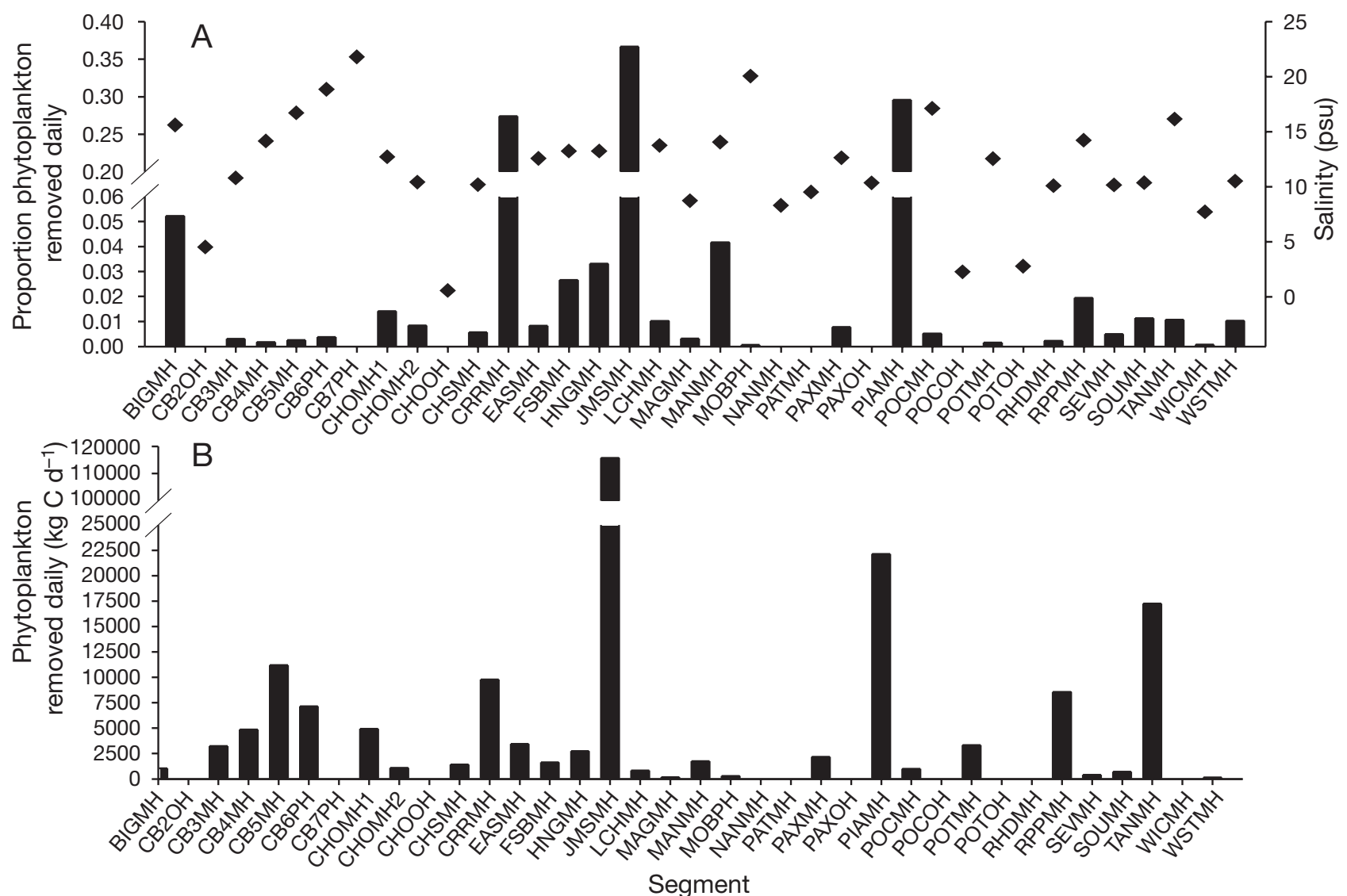

Fig. 3. Mean daily oyster clearance of phytoplankton in July at current oyster biomass given as: (A) the proportion of phytoplankton biomass available and; (B) as kilograms of C per day. Mean salinity data are given for each segment in top chart ( $\bullet$ ) for reference. Segment names ending in $\mathrm{MH}, \mathrm{OH}$, or $\mathrm{PH}$ are mesohaline, oligohaline, or polyhaline segments, respectively. See Table 1 for a full description of each segment
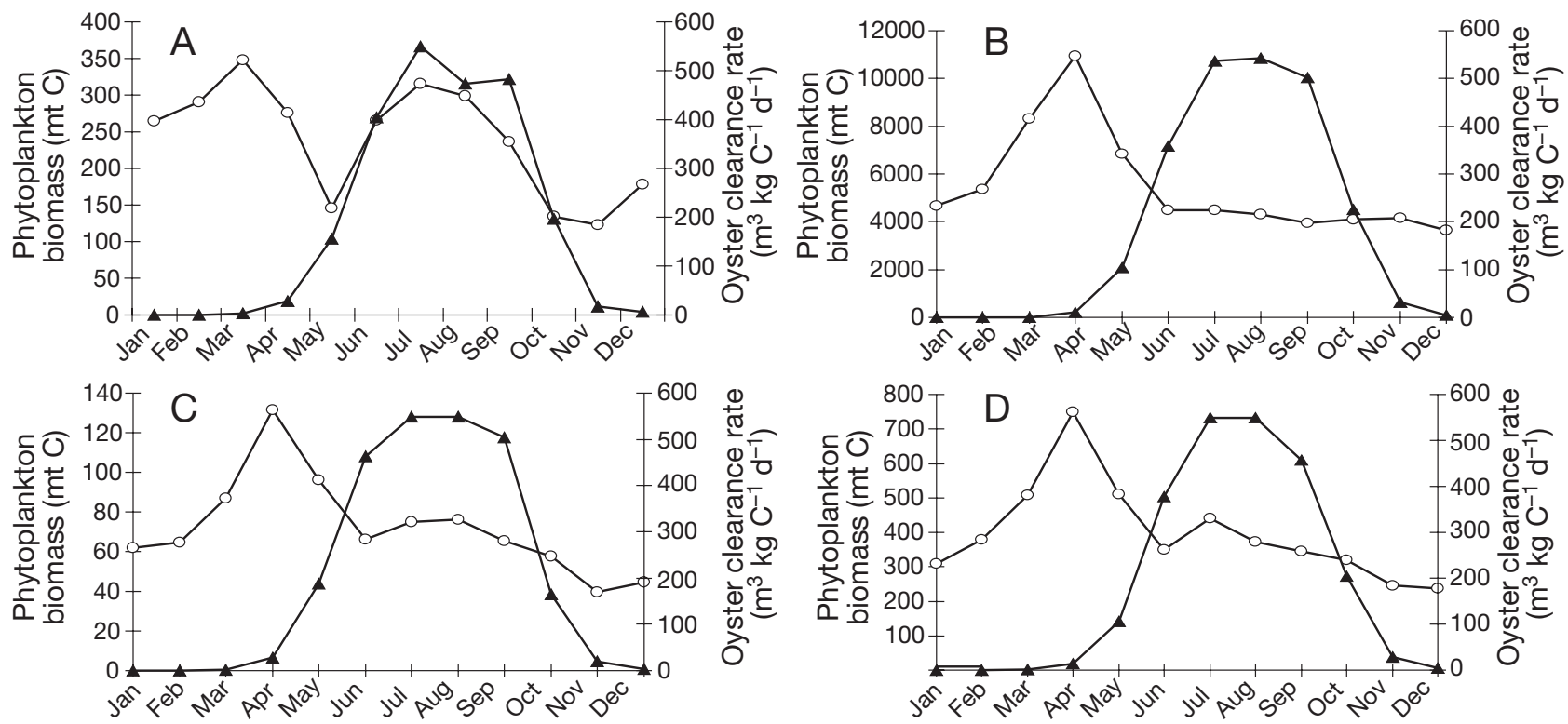

Fig. 4. Monthly mean phytoplankton biomass $(\mathrm{O})$ and monthly mean oyster clearance rate $(\mathbf{\Delta})$ estimated with the filtration model across a range of segment sizes and locations. Data are for the mesohaline segments of the: (A) James River; (B) Rappahannock River; (C) Piankatank River; and (D) mesohaline section of the mainstem bay 


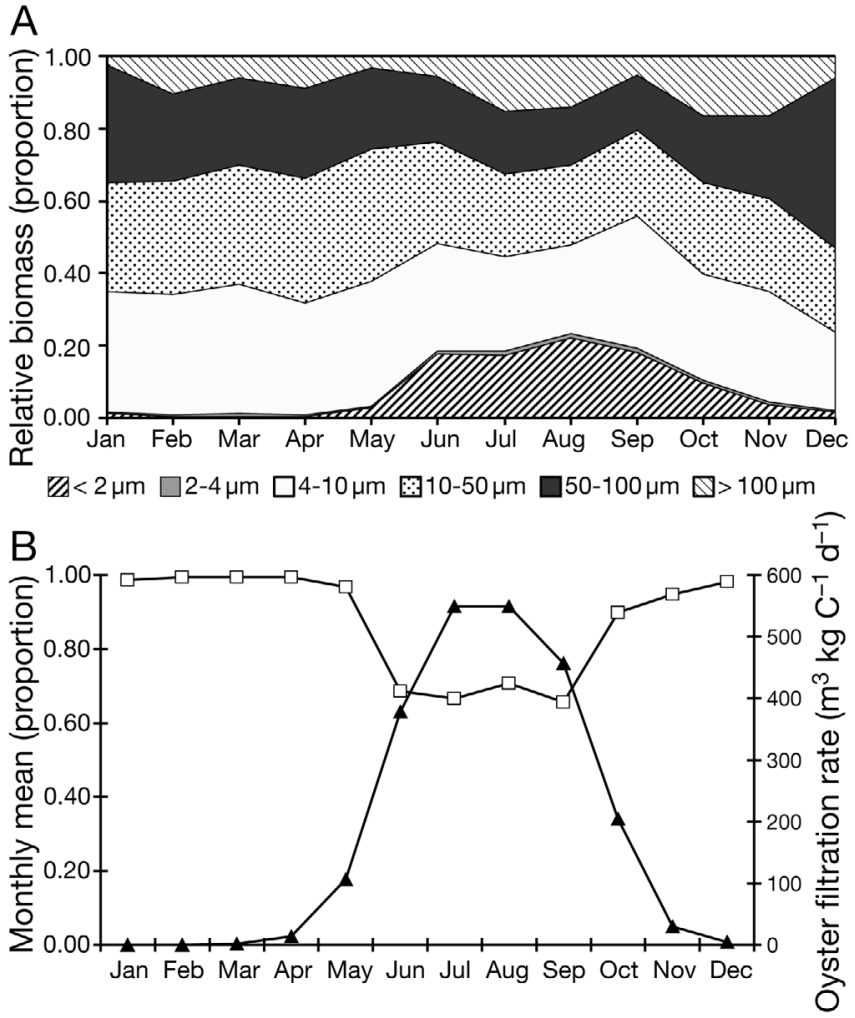

Fig. 5. Seasonal patterns in: (A) phytoplankton-relative biomass by size category; and (B) oyster daily clearance rate ( $(\boldsymbol{A})$ estimated with the oyster filtration model, and relative biomass ( $\square$ ) of phytoplankton $\geq 2 \mu \mathrm{m}$ for the mesohaline segment of the Rappahannock River. Size categories in Panel A are arranged in descending order from top to bottom $(>100$, $50-100,10-50,4-10,2-4,<2 \mu \mathrm{m})$

\section{Model sensitivity to picoplankton cell size estimates}

Variation in the estimate of picoplankton cell size, which affected both predicted relative biomass of small cells and oyster filtration efficiency, had only a minor effect on estimates of the proportion of phytoplankton biomass cleared by oysters. On an annual basis the low value for picoplankton-relative biomass (based on a $0.8 \mu \mathrm{m}$ cell diameter) resulted in an increase of $3.7 \%$ in the proportion of phytoplankton removed from the whole bay relative to the nominal value (based on $1 \mu \mathrm{m}$ cell diameter). An increase in picoplankton-relative biomass to the high value $(2 \mu \mathrm{m}$ cell diameter) resulted in a decrease of $0.63 \%$ above the nominal value in the estimate of phytoplankton removed daily from the whole bay. The direction and magnitude of the response to a change in picoplankton cell diameter reflected both the effect of picoplankton size on the percent of total phytoplankton biomass comprised of picoplankton-size cells, and the effect of cell size on oyster retention efficiency. These changes in model response peaked in July at 7.9 and $0.89 \%$, respectively. The response of model estimates of total oyster clearance in individual segments did not differ substantially from the bay-wide effect.

\section{Modeling alternative oyster restoration strategies}

We did not explicitly consider phytoplankton growth in our model analysis, so our model does not predict the effect of changing oyster biomass on phytoplankton concentration. We can, however, compare our model predictions of phytoplankton removal to estimates of phytoplankton daily growth as a qualitative assessment of whether oysters are removing phytoplankton biomass at or above replacement levels. Depth-integrated estimates of daily specific primary productivity in the euphotic zone expressed as net maximum carbon fixation ( $\mathrm{g} \mathrm{C}^{-1}$ phytoplankton $\mathrm{C} \mathrm{d}^{-1}$ ) for phytoplankton in Chesapeake Bay range from $0.006 \mathrm{~d}^{-1}$ in February to $1.36 \mathrm{~d}^{-1}$ in July, with an annual mean of $0.35 \mathrm{~d}^{-1}$ (Bay Monitoring Program Data 2002 to 2003, R. Lacouture unpubl. data; Harding et al. 2002). These primary production estimates do not account for costs of production, but they can be considered an estimate of maximum growth rates for phytoplankton in Chesapeake Bay.

In the mainstem of the bay, 10-, 25-, and 100-fold increases in oyster biomass without redistribution resulted in 10-, 25-, and 100-fold increases in the proportion of phytoplankton removed daily by oysters (Fig. 6A). Removal rates with even the highest increases in oyster biomass were low in comparison to our estimate of annual mean phytoplankton production in the mainstem Chesapeake Bay. The redistribution and limited harvest scenarios resulted in no change in the mainstem as these scenarios did not increase oyster biomass in these areas.

Both the average percent of phytoplankton cleared by oysters in tributaries (not weighted by tributary volume), and the number of tributary segments in which phytoplankton removal was predicted to exceed production, varied among the restoration scenarios tested. The increase in the amount of phytoplankton removed daily by oysters in the tributaries in response to a 10 -fold increase in oyster biomass varied by a factor of 3 among the different approaches to achieving this restoration goal based on the un-weighted average across all tributary segments (Fig. 6B). An increase in oyster biomass without a change in distribution resulted in an increase in daily phytoplankton removal from 1.5 to $15 \% \mathrm{~d}^{-1}$ averaged across all tributary segments, and phytoplankton removal exceeding replacement in 3 segments - the James, Corrotoman, and Piankatank Rivers (Fig. 7). A 10-fold increase in oyster biomass combined with redistribution focused in 


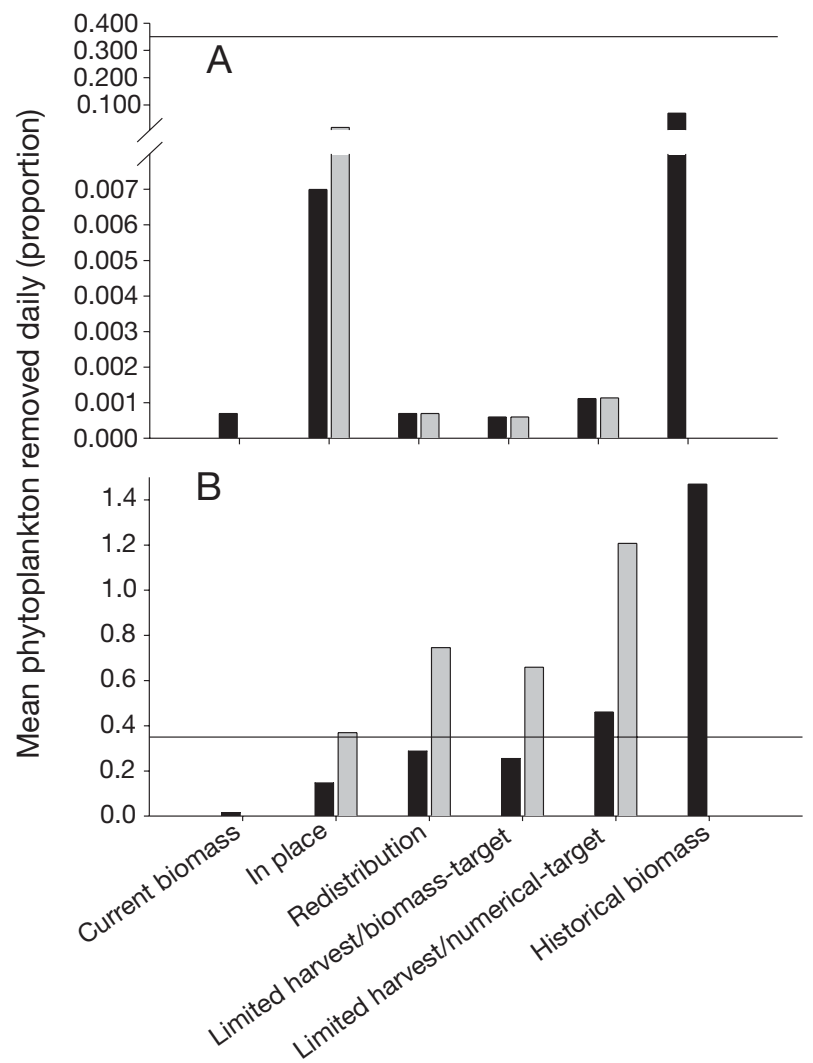

Fig. 6. Mean daily removal of phytoplankton biomass by oysters estimated with the oyster filtration model for (A) the mainstem of Chesapeake Bay and (B) averaged across all tributaries, based on a 10-fold (black bars) and a 25 -fold (grey bars) increase in oyster biomass under different scenarios for oyster distribution and individual size. A reference line is given at the annual mean maximum specific growth rate $\left(\mathrm{d}^{-1}\right)$ for phyto-

plankton. See Table 2 for details on different scenarios
Tangier Sound, as well as the Choptank and Rappahannock Rivers, resulted in an increase in the unweighted average daily phytoplankton removed to $29 \% \mathrm{~d}^{-1}$ across all tributaries. Under this restoration scenario, the number of segments in which phytoplankton removal was predicted to exceed replacement increased to 5, with removal in 2 segments predicted to be twice the replacement level or higher (Fig. 7).

The 25-fold increase in oyster biomass was consistent in pattern with the 10-fold increase across restoration scenarios, with the exception that phytoplankton removal was predicted to exceed the maximum phytoplankton growth rate averaged across all tributaries (Fig. 6B). Predicted removal exceeded phytoplankton replacement in 5 tributaries for 'in place' restoration and 10 for the redistribution scenario.

The effect of altering the size distribution of oysters differed depending on whether numerical density or biomass was held to levels comparable to scenarios that modeled uniformly sized $1 \mathrm{~g}$ DW oysters. Oyster biomass in the limited harvest/numerical-target scenario increased 20 -fold at numerical densities equal to those in the 10-fold increase in $1 \mathrm{~g}$ DW oysters in the redistribution scenario. As a result, phytoplankton removal increased to $46 \% \mathrm{~d}^{-1}$ across all tributaries, and the number of tributary segments in which removal was predicted to exceed replacement increased to 6 (Fig. 7). In contrast, an increase in average individual size with the oyster biomass limited to a 10 -fold increase (limited harvest/biomass-target scenario) resulted in phytoplankton removal of $25.5 \% \mathrm{~d}^{-1}$ averaged across all tributary segments, which is less than the predicted increase in the redistribution sce-

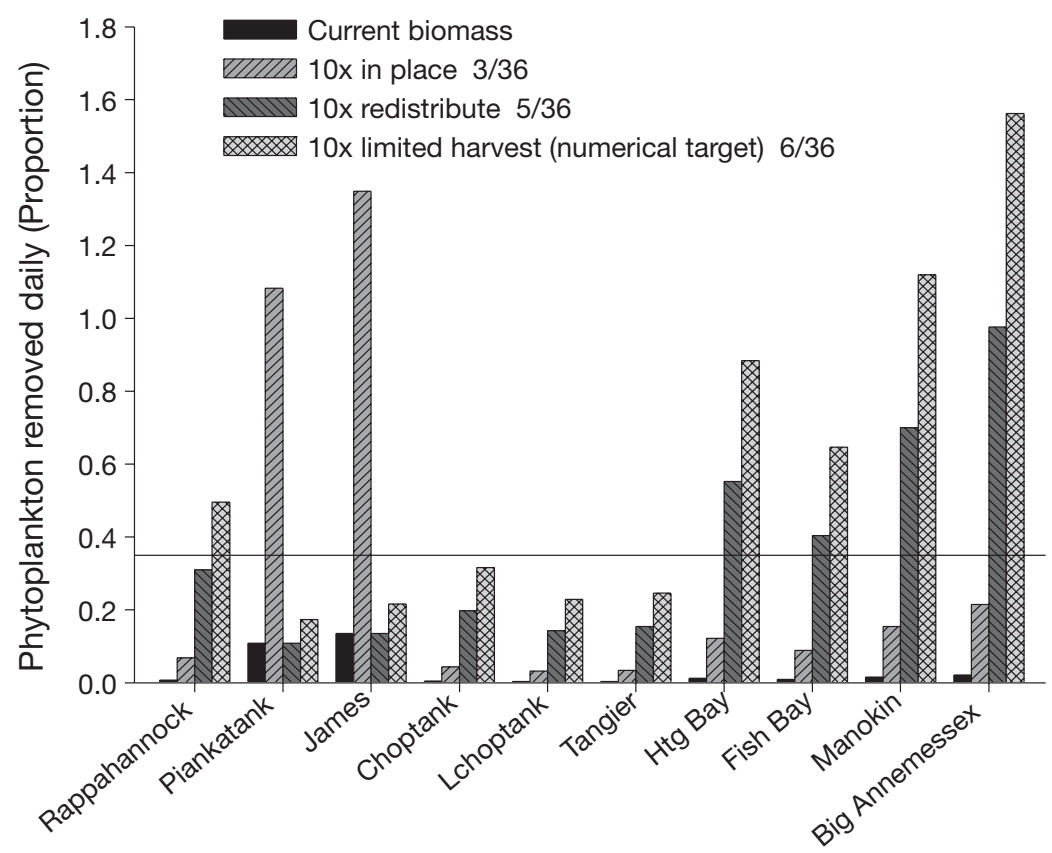

Fig. 7. Mean across all seasons of phytoplankton removed daily by oysters predicted by the model in selected individual segments (10 of 36) based on model results for 4 restoration scenarios. An index of local effects is given in the legend for each restoration scenario measured as the number of segments out of 36 in which oysters are predicted to remove phytoplankton at or above the replacement level defined by net primary productivity. Not all of the segments reflected in this index are displayed. Reference line (black) is given at the annual mean maximum specific growth rate $\left(\mathrm{d}^{-1}\right)$ for phytoplankton. See Table 2 for details on different scenarios. Physical details for these ten segments can be found in Table 1 by segment codes: RPPMH, PIAMH, JMSMH, CHOMH2, LCHMH, TANMH, HNGMH, FSBMH, MANMH, and BIGMH respectively 
nario with uniformly sized oysters. This reduction in total phytoplankton removal occurs because weightspecific filtration decreases as individual oyster biomass increases, and the limited harvest/biomass-target scenario does not allow for a compensatory increase in total population biomass. At numerical densities equivalent to those in the 25-fold biomass increase of $1 \mathrm{~g} \mathrm{DW}$ oysters, phytoplankton removal was predicted to exceed replacement in 10 tributary segments.

The seasonal pattern of the oyster filtration rate closely matched the seasonal pattern of net maximum primary productivity reported in the literature for the mainstem of the bay and for the Patuxent River (Fig. 8; Bay Monitoring Program Data 2002 to 2003, R. Lacouture unpubl. data; Harding et al. 2002). Removal of phytoplankton by oysters was highest in the summer in both the mainstem and the Patuxent River, but even at the highest oyster biomass levels examined in this analysis (100-fold current biomass, i.e. pre-1870 biomass) at maximum summer clearance rates, oysters were predicted to remove phytoplankton above the phytoplankton replacement rate in the Patuxent River (Fig. 8A), but not in the mainstem of the bay (Fig. 8B). Model results also suggested that oyster removal of phytoplankton in the mainstem and Patuxent River at 100-fold current oyster biomass in March and April is $\sim 1 \% \mathrm{~d}^{-1}$, which is still below the maximum net
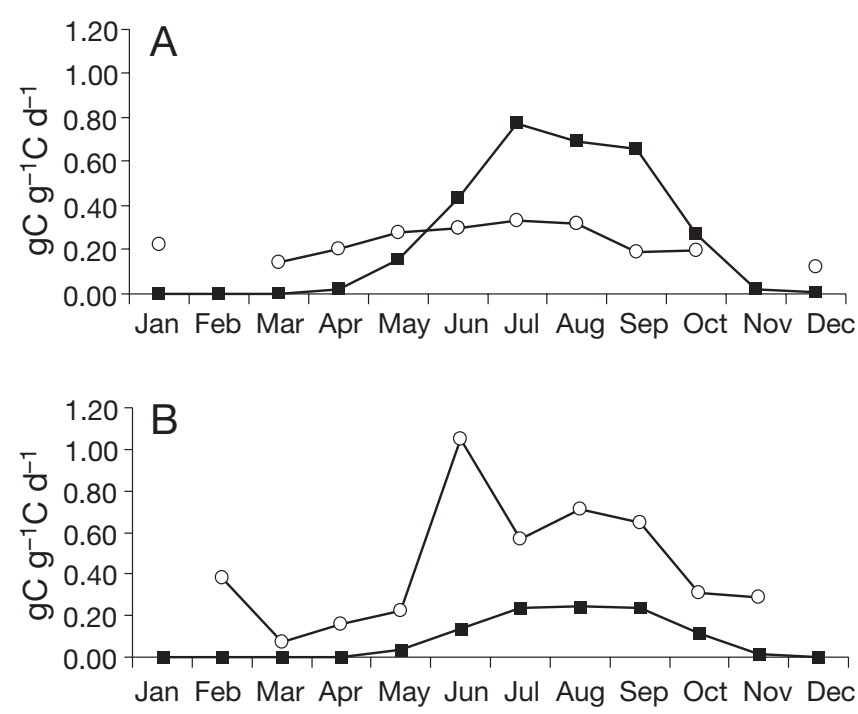

Fig. 8. Mean monthly proportion of phytoplankton removed by oysters ( $\mathbf{\square})$ and mean monthly net maximum specific primary productivity (O) for the (A) Patuxent River, Maryland, and the (B) mesohaline section of the mainstem bay. Estimates of phytoplankton removed by oysters are model predictions at 100 -fold current oyster biomass. Net maximum primary productivity data are based on ${ }^{14} \mathrm{C}$ uptake measurements taken at seasonally explicit surface light levels and water temperature. See 'Results' for sources of primary productivity data replacement rate for phytoplankton $\left(17.6 \% \mathrm{~d}^{-1}\right)$ during these months under current nutrient-enriched conditions in Chesapeake Bay.

\section{DISCUSSION}

\section{Predicted removal of phytoplankton under a range of oyster restoration scenarios}

The influence of oyster feeding on phytoplankton biomass in Chesapeake Bay is severely limited at present by low oyster abundance caused by over a century of over-harvesting and more recent disease epizootics (Rothschild et al. 1994, Jordan \& Coakley 2004). At the scale of the entire bay, the mean daily estimate of maximum phytoplankton growth rate $\left(35 \% \mathrm{~d}^{-1}\right)$ is 1 to 2 orders of magnitude above our calculated annual mean estimate of the rate at which the current oyster population removes phytoplankton (non-volumeweighted; mainstem $0.07 \% \mathrm{~d}^{-1}$, tributaries $1.4 \% \mathrm{~d}^{-1}$ ). Our results indicate that a 10 -fold increase in oysters will have little discernable effect on phytoplankton biomass bay-wide. It should be noted that as ambitious as a restoration goal of a 10-fold increase in oyster biomass may seem, it would still only return oysters to $<10 \%$ of their pre-exploitation abundance. A higher restoration target on the order of 25-fold current biomass may be required to achieve a meaningful reduction in phytoplankton biomass under the current nutrient-enriched conditions in Chesapeake Bay.

Our model predicted that at near-historic oyster biomass levels (100-fold increase) oysters would filter a water volume equal to the entire volume of the bay in about $27 \mathrm{~d}$, as an annual average, and in about $9 \mathrm{~d}$ at peak summer clearance rates, which is consistent with previous estimates of water filtration by oysters reported by Newell (1988). This historical biomass comparison does not imply that such a level of restoration would return Chesapeake Bay to its original pristine condition. Rather, it is intended to provide a useful benchmark for evaluating other restoration scenarios. These high predicted filtration rates translated to a removal of phytoplankton averaged across all segments examined of $31 \% \mathrm{~d}^{-1}$, and averaged across all tributary segments (mainstem excluded) in excess of $100 \% \mathrm{~d}^{-1}$. Such a high historical biomass of oysters may have been more dependent on other sources of food such as allochthonous detritus, higher organic content of resuspended sediment, or on a higher primary production rate resulting from much tighter nutrient recycling and increased light penetration than is present today (Newell et al. 2005). The actual amount of phytoplankton removed by such an abundant oyster population is also likely lower than our 
model calculations suggest due to spatial constraints and the refiltration of water (see below).

An important implication of our analysis is that largescale ecological benefits of increasing oyster biomass, as indexed here by phytoplankton removal, are dependent on local conditions and decisions about where and how oysters are restored. Increasing oyster biomass in a limited number of areas increased the number of tributary segments in which oysters were predicted to remove phytoplankton at or above replacement levels. The pattern of oyster redistribution used in this analysis was focused in areas of Chesapeake Bay that contained historically large oyster populations, but there are many possible variants on this basic theme for planning oyster restoration. The model used in this analysis is highly flexible and can easily be applied for assessments other than those presented here. The number of local areas predicted by our model analyses where restoration goals were achieved is also a useful index for gauging the regional benefit of restoration based on multiple local restoration efforts.

A recent review of the potential effect of oyster population recovery on hypoxia in Chesapeake Bay dealt qualitatively with many of the same issues we raise here regarding the importance of spatial and temporal coincidence of oysters and phytoplankton for maximizing the ecological impact of increasing oyster biomass (Pomeroy et al. 2006). While we agree with some of the issues raised by Pomeroy et al. (2006), our more quantitative analysis indicates that increasing oyster biomass can lead to substantial reductions in phytoplankton abundance under certain conditions. Furthermore, our model provides a rational basis for assessing alternative oyster restoration strategies.

Our predicted minimal effect on phytoplankton biomass that would result from a 10-fold increase in oyster biomass is consistent with the findings of another recent model on the water-quality benefits of oyster enhancement in Chesapeake Bay (Cerco \& Noel 2005). Results of a network model analysis of oyster recovery in Chesapeake Bay (Ulanowicz \& Tuttle 1992) agree with our findings in direction, but predict a stronger effect of oysters on phytoplankton biomass. Ulanowicz \& Tuttle (1992) referred to their modeling approach as a 'rough approximation' of the effects of oyster recovery. In particular, their approach involved both spatial and temporal averaging and did not address the mismatch issues we have pointed out as potentially important (discussed below). Another model analysis similar to ours on the ecological value of restoration of bivalve populations in Rhode Island indicated that different restoration actions such as limiting harvest or seeding the population with new juveniles resulted in different benefits based on the bivalve species targeted for restoration (McCay et al. 2003). Their findings suggest that comparative studies of different plans for restoration can also be highly beneficial in more diverse bivalve communities than the one under study here, and our model is highly adaptable to such general analyses.

Our results also indicate that restoration strategies that affect size distributions of oysters can affect total phytoplankton removal, as well as the number of segments in which phytoplankton removal exceeds replacement. In the scenarios presented here, a change in the size distribution of oysters, resulting in an increased mean size and the same numerical density of oysters in the model, determined whether phytoplankton removal by oysters was below or above replacement levels in the Rappahannock River. It is also noteworthy that the number of local segments in which oysters were predicted to remove phytoplankton at or above replacement levels increased when the size distribution increased and numerical density was held equal to a 10-fold biomass increase in $1 \mathrm{~g}$ DW oysters. No increase in this metric was evident, however, when numerical density was held equal to a 25 -fold increase, suggesting a potentially important trade-off between total population biomass and the value of protecting larger individuals.

Oyster size distribution is dealt with simply in this model analysis as a homogenous population of $1 \mathrm{~g}$ DW individuals in 3 scenarios and a limited harvest scenario with a mixture of 1 and $3 \mathrm{~g}$ DW individuals in another scenario. Although total oyster biomass was calculated based on observed size distributions at stations throughout Chesapeake Bay, our computed total filtration rates do not account for spatial/temporal variations in population size distribution. This simplification allowed us to calculate a more straightforward comparison among locations and restoration strategies without the potentially confounding and poorly documented effects of spatial variation in the influence of disease, harvest, and other factors on oyster size distributions.

The primary objective of many oyster restoration activities along the Atlantic coast and the Gulf of Mexico is enhancement of the commercial fishery rather than an enhancement of ecosystem services (Mackenzie et al. 1997, Soniat et al. 2004). The importance of an increased oyster population for reducing phytoplankton biomass and improving water quality may be enhanced in Chesapeake Bay by high public awareness of the issue of nutrient over-enrichment, and the historical precedent for the importance of eastern oysters. This dual emphasis on the economic and ecological importance of oysters has created multiple interest groups for oyster restoration in Chesapeake Bay with seemingly disparate objectives. However, the importance of oysters as ecological and fishery resources need not be mutually exclusive. Effective planning of 
restoration that involves partial harvest protection to provide a steady larval supply has been suggested as an effective strategy to accomplish both restoration objectives (Breitburg et al. 2000). Our analysis suggests that this strategy will require a larger total biomass of oysters to gain equivalent phytoplankton removal benefits if harvest protection results in a larger mean oyster size. The important point is that there are trade-offs to consider between oyster restoration for economic and ecological purposes, and an analysis of these trade-offs should occur earlier rather than later in the restoration planning process to reduce user-group conflicts.

\section{Constraints on oyster filtration of phytoplankton}

The influence of oysters on phytoplankton biomass is limited in most bay areas by low present-day oyster biomass, but it is also limited by spatial and temporal mismatches between oysters and phytoplankton in the Chesapeake Bay system. Increasing oyster biomass will increase phytoplankton removal and increase water clarity. Yet, on a bay-wide basis, the effects of oysters on phytoplankton are constrained by 3 factors: (1) the bulk of present-day oyster biomass is in tributaries, while the bulk of phytoplankton is in the mainstem Chesapeake Bay; (2) maximal rates of oyster filtration occur at temperatures higher than those at which phytoplankton biomass peaks in the spring; and (3) maximal rates of oyster filtration coincide temporally with maximum relative abundance of picoplankton, which are not efficiently retained by oysters.

The present-day patchy distribution of eastern oysters is quite different from their more even distribution when they were at their historic peak biomass (Smith et al. 2001, 2003). The current spatial mismatch between oyster populations and phytoplankton biomass can be minimized to some degree through targeted restoration. However, the spatial mismatch may limit oyster effects even more strongly than our calculations suggest. Oysters are benthic animals, and they are predominantly located on the shallow flanks of the mainstem bay and its tributaries. Considerable phytoplankton production occurs in the pelagic zone, away from nearshore littoral areas, and so this biomass is only available to benthic grazers as a result of tidaland wind-generated mixing processes. There is some level of uncertainty concerning exactly how much of the phytoplankton over the central channel of the bay will be made available through wind and tidal mixing to oysters, and therefore how effective oysters will be in removing phytoplankton from the water column. In our model we assumed that oysters had access to all phytoplankton in the surface mixed layer. Surface- layer phytoplankton biomass, which does not move to where oysters are located due to distance or absence of physical forcing, will be unavailable to oysters and will not be grazed.

The importance to model predictions of the assumption that oysters have access to the entire surface mixed layer will vary spatially and temporally based on oyster filtration activity, water movement, and with depth and width of the surface mixed layer. Gerritsen et al. (1994) estimated that the percentage of the surface mixed layer available to suspension-feeding benthic organisms varied between $100 \%$ in the Potomac and Patuxent Rivers to $16 \%$ in the mesohaline main bay. Hagy (2002) estimated this proportion at between 43 and $51 \%$ bay-wide. Because most of the oyster biomass is located today in the tributaries, access to the surface mixed layer should not greatly affect our estimates of current bay-wide oyster filtration effects; the importance of access to the surface mixed layer for estimates on the effects of increased oyster biomass will depend on the locations in which oyster biomass increases.

Although it may be possible to focus oyster restoration efforts in the mainstem bay, where most phytoplankton biomass is located, oyster access to phytoplankton would still be limited by the relative size of the pelagic zone and local hydrodynamic conditions. Choosing areas with a high ratio of littoral to pelagic habitat for local restoration will result in a greater local improvement in water quality by increasing oyster access to phytoplankton. Larger oyster reefs will also serve to increase bottom roughness and increase water column mixing of phytoplankton to deep waters (Newell 1988, Lenihan 1999). Nevertheless, even if oyster distributions shifted, the bay-wide water-quality effect of oyster restoration will still be limited by the fact that most phytoplankton is concentrated in the mainstem of the bay, where lateral mixing may be insufficient to deliver all of the phytoplankton biomass to oysters in nearshore, shallow waters (Gerritsen et al. 1994, Hagy 2002). Oyster restoration in the bay's tributaries may also affect phytoplankton biomass in the mainstem of the Chesapeake Bay by intercepting phytoplankton biomass, and thereby reducing transport of associated nutrients and organic carbon from tributaries to the mainstem (Boynton et al. 1995). Although our model is not designed to address such indirect effects, they may be important at regional scales.

There is also a temporal mismatch between oyster activity and the spring peak in phytoplankton biomass in most bay regions. The period of maximum phytoplankton biomass occurs in March or April, prior to the period of maximum oyster clearance that occurs from June through September. The spring peak in phytoplankton biomass is thought to result from a general 
lack of grazing pressure on phytoplankton in the spring (Malone 1992). The importance of this temporal mismatch is that any increase in oyster biomass may have a limited effect on size of the spring phytoplankton bloom or the contribution of the spring bloom to bottom-water hypoxia in the summer (Malone 1992). The temperature-mediated constraint on oyster filtration may also lead to important differences in the benefits of oyster restoration and nutrient-reduction strategies that reduce springtime nutrient delivery to Chesapeake Bay as management tools for improving water quality.

Our use of monthly mean temperatures may, however, have resulted in an underestimate of oyster grazing of phytoplankton during late winter and early spring. Oyster clearance rates increase exponentially with increasing water temperature between 5 and $17^{\circ} \mathrm{C}$ (Newell \& Langdon 1996), which represents the range of mean seasonal temperature increase from February to April. Our use of monthly mean temperatures may result in us underestimating phytoplankton removal in months when water temperatures are increasing rapidly because the non-linear bias on clearance rate estimates increases with increasing withinmonth temperature range. Higher removal during late winter and spring than we estimated from monthly means, when phytoplankton replacement rates are at their lowest, could result in removal exceeding replacement under more scenarios than the current model predicts. The importance of the seasonal mismatch between maximum oyster clearance rates and maximum phytoplankton biomass is also dependent on realized phytoplankton production rates in the spring, as well as the influence of other consumers. We are investigating these complex seasonal interactions more fully in an ongoing analysis of possible changes in food web dynamics associated with oyster restoration.

The potential impact of oyster clearance on phytoplankton biomass in our model was also influenced by the seasonal patterns in phytoplankton size composition. Oysters can efficiently filter phytoplankton cells and detritus $>4 \mu \mathrm{m}$ in diameter (Langdon \& Newell 1990). For cells smaller than $<4 \mu \mathrm{m}$, clearance efficiency drops rapidly and is near zero for cells smaller than $2 \mu \mathrm{m}$. Therefore, the portion of the phytoplankton biomass represented by cells $1 \mu \mathrm{m}$ or smaller is largely unavailable to oysters.

Our analysis indicates that the mean relative biomass of picoplankton peaks in the summer at $22 \%$ of total phytoplankton biomass, but this value has been reported to be as high as $50 \%$ of total phytoplankton biomass in some areas (Lacouture et al. 1990). Data on the spatial and temporal variation in the peak seasonal abundance of picoplankton in Chesapeake Bay are limited. Values for peak summer abundance for vari- ous locations in the bay and its tributaries range from 8 to $53 \%$ of the total phytoplankton biomass (Ray et al. 1989, Lacouture et al. 1990, Youngsik et al. 2000, K. Sellner, Chesapeake Research Consortium, unpubl. data). Our conversions of Bay Monitoring Program picoplankton count data resulted in a range of 7 to $48 \%$ in July and August across all segments for which data are available, and these data are in general agreement with literature reports.

This seasonal pattern in picoplankton abundance results in a decrease in phytoplankton biomass available to oysters during the time of year characterized by highest oyster clearance rates. This size-selective oyster filtration may result in increasing the relative biomass of picoplankton during summer (Newell 2004). The production rate of picoplankton is the highest of all size classes, and they may have more access to nutrients than their larger-celled competitors, thereby increasing their production (Malone 1992).

\section{Influence of physical variability on model predictions}

Seston concentration and salinity also had large effects on our predictions of phytoplankton removed by oysters. Data suggest that oyster feeding increases rapidly with increasing seston concentration, and a value between 4 and $25 \mathrm{mg} \mathrm{l}^{-1}$ is optimal for oyster clearance (Jordan 1987), but the effect of higher seston concentrations on oyster clearance is not completely clear. If oysters continue to filter water at close to the maximum rate at seston concentrations between 45 and $100 \mathrm{mg} \mathrm{l}^{-1}$, as our nominal function predicts, then the amount of phytoplankton removed by oysters will be higher than predicted by other modeling approaches that constrain oyster feeding at high seston loads (Cerco \& Noel 2005). This influence is confined to the higher turbidity segments (e.g. James River) and, in other segments, to periods of above-average freshet events.

Oysters were not predicted to remove significant amounts of phytoplankton biomass from the water column in areas where mean monthly salinity was $<5$. The effect of salinity on oyster filtration was most evident in the oligohaline regions of the bay. Eastern oyster populations do exist in low-salinity areas, although they grow at about half the rate of oysters living in higher salinity waters (M. Tarnowski, Maryland Department of Natural Resources, unpubl. data). Within-month variation in salinities in oligohaline areas will result in some days during which oysters can feed during months when mean salinities were below the threshold for oyster filtration in our model. As a result, our model underestimates oyster filtration dur- 
ing some months in these segments. Nevertheless, the qualitative prediction of our model is sound; phytoplankton removal in oligohaline areas will be substantially lower than in mesohaline areas at comparable biomass levels.

Our model predictions are also based on the assumption that oysters do not re-filter the same parcel of water. Gerritsen et al. (1994) developed a probalistic model that indicated that at present-day low oyster densities the re-filtration of a parcel of water is low. The Gerritsen et al. (1994) model also suggested that as oyster density, and the volume cleared per day, increases, the amount of water re-filtered also increases. The values estimated from their probability-based model are unlikely to reflect the actual physics of water movement in the bay. Generally, oyster beds are concentrated in areas of high water flow and scour, such as occur along the edges of channels, where water movement is sufficient to bring in food and remove biodeposits (Lund 1957). Further, the large reefs that develop with enhanced oyster biomass will protrude up into the water column and thereby enhance turbulent mixing and create changes in the local water currents (Lenihan 1999). The resulting increases in water circulation will likely enhance the ability of oysters to filter large amounts of particulate material and increase their access to a greater proportion of phytoplankton biomass (Newell 1988).

\section{CONCLUSIONS}

Our findings suggest that the ecological value of an increase in oyster biomass may only be accurately assessed by considering how variation in spatial, temporal, and size distributions of phytoplankton align with oyster densities, filtration rates, and retention efficiencies. Oyster restoration will make the greatest contribution towards reducing local phytoplankton biomass where oysters have access to surface-layer chl $a$, where picoplankton comprise a modest proportion of summer phytoplankton biomass, and where the contribution of the spring bloom to total annual phytoplankton biomass is low. In general, bay-wide effects of oyster restoration may be more readily achieved by a strategy of maximizing the spatial distribution of successful local restoration efforts in smaller, shallower bay segments. Management strategies that increase the mean size of oysters can provide substantial ecological and fishery benefits because of habitat provision and broodstock protection, but will ultimately require higher oyster biomass to achieve equal filtration capacity.

Despite the fact that oysters currently have a negligible effect on bay phytoplankton biomass, our 100-fold simulations of putative pre-exploitation abundances of oysters indicate that oyster may once have made an important contribution to maintaining water clarity and controlling phytoplankton biomass. While our present model analysis does not provide a comprehensive prediction of ecological effects, our focus on reductions in phytoplankton biomass provides a useful basis for comparisons among alternative plans for oyster restoration. Whether or not a particular oyster restoration target can be achieved, the cultural and ecological benefits of increasing oyster biomass in Chesapeake Bay are considerable and make oyster restoration an important objective for improving the bay ecosystem. To be successful, restoration plans need to consider local conditions, but aim for a bay-wide effect. The modeling approach provided here can be a valuable tool for assessing the benefit-to-cost ratio of various restoration scenarios and thus maximizing the use of resources for achieving oyster restoration goals. Model analyses, such as this one, that are flexible and accessible to a large user group (e.g. management planners) can also be highly useful for evaluating the specific benefit of increasing the biomass of benthic filter-feeding populations in other similar systems and provide a basis for comparison of the value of benthic filter feeders for the remediation of cultural eutrophication in coastal estuaries.

Acknowledgements. We thank Roger Mann and Carl Cerco for their assistance in obtaining bay-wide estimates of oyster biomass and for discussions and advice on the functions used for estimating oyster clearance rates. Richard Lacouture, Kevin Sellner, Charles Gallegos, and Harold Marshall provided data and advice on the size segregation of phytoplankton data, as well as biomass estimates for individual taxonomic groups. This work was funded by grants from the EPA Chesapeake Bay Program and the NOAA Coastal Ocean Program.

\section{LITERATURE CITED}

Bayne BL (1971a) Oxygen consumption by three species of lamellibranch mollusc in declining ambient oxygen tension. Comp Biochem Physiol A 40:955-970

Bayne BL (1971b) Ventilation, the heart heat and oxygen uptake by Mytilus edulis L. in declining oxygen tension. Comp Biochem Physiol A 40:1065-1085

Boicourt BL (1992) The influences of circulation processes on dissolved oxygen in Chesapeake Bay. In: Smith D, Leffler M, Mackiernan G (eds) Dissolved oxygen in Chesapeake Bay. Maryland Sea Grant, College Park, MD, p 7-59

Boynton WR, Garber JH, Summers R, Kemp WM (1995) Input, transformations, and transport of nitrogen and phosphorus in Chesapeake Bay and selected tributaries. Estuaries 18: 285-314

Breitburg DL (1990) Nearshore hypoxia in the Chesapeake Bay: patterns and relationships among physical factors. Estuar Coast Shelf Sci 30:593-609

Breitburg DL, Coen LD, Luckenbach MW, Mann R, Posey M, Wesson JA (2000) Oyster reef restoration: convergence of harvest and conservation strategies. J Shellfish Res 19:371-377 
Brumbaugh RD, Sorabella LA, Garcia CO, Goldsborough WJ, Wesson JA (2000) Making a case for community-based oyster restoration: an example from Hampton Roads, Virginia, USA. J Shellfish Res 19:467-472

Cerco CF, Noel MR (2005) Evaluating ecosystem effects of oyster restoration in Chesapeake Bay. Report submitted to the Maryland Department of Natural Resources, Annapolis. Available at http://www.chesapeakebay.net/ pubs/Cerco_Noel_final.pdf

Cloern JE (1982) Does the benthos control phytoplankton biomass in south San Francisco Bay? Mar Ecol Prog Ser 9: 191-202

Cloern JE (2001) Our evolving conceptual model of the coastal eutrophication problem. Mar Ecol Prog Ser 210:223-253

Cloern JE, Grenz C, Vidergar-Lucas L (1995) An empirical model of the phytoplankton chlorophyll:carbon ratio - the conversion factor between productivity and growth rate. Limnol Oceanogr 40:1313-1321

Correll DL, Jordan TE, Weller DE (1999) Transport of nitrogen and phosphorus from Rhode River watersheds during storm events. Water Resour Res 35:2513-2521

Correll DL, Jordan TE, Weller DE (2000) Transfer of phosphorus from the farm to the bay. In: Sharpley AN (ed) Agriculture and phosphorus management: the Chesapeake Bay. Lewis Publishers, Washington, DC, p 131-142

Cressman KA, Posey MH, Mallin MA, Leonard LA, Alphin TD (2003) Effects of oyster reefs on water quality in a tidal creek estuary. J Shellfish Res 22:753-762

Dame RF (1996) Ecology of marine bivalves: an ecosystem approach. CRC Press, Boca Raton, FL

Fear J, Gallo T, Hall N, Loftin J, Paerl H (2004) Predicting benthic microalgal oxygen and nutrient flux responses to a nutrient reduction management strategy for the eutrophic Neuse River Estuary, North Carolina, USA. Estuar Coast Shelf Sci 61:491-506

Gallegos CL (2001) Calculating optical water quality targets to restore and protect submersed aquatic vegetation: overcoming problems in partitioning the diffuse attenuation coefficient for photosynthetically active radiation. Estuaries 24:381-397

Gerritsen J, Holland AF, Irvine DE (1994) Suspension-feeding bivalves and the fate of primary production: an estuarine model applied to Chesapeake Bay. Estuaries 17:403-416

Hagy JD (2002) Eutrophication, hypoxia and trophic transfer efficiency in Chesapeake Bay. PhD dissertation, University of Maryland, Cambridge

Hagy JD, Boynton WR, Keefe CW, Wood KV (2004) Hypoxia in Chesapeake Bay, 1950-2001: long-term change in relation to nutrient loading and river flow. Estuaries 27:634-658

Harding JM, Mann R (1999) Fish species richness in relation to restored oyster reefs, Piankatank River, Virginia. Bull Mar Sci 65:289-299

Harding LW, Mallonee ME, Perry ES (2002) Toward a predictive understanding of primary productivity in a temperate, partially stratified estuary. Estuar Coast Shelf Sci 55: 437-463

Jordan SJ (1987) Sedimentation and remineralization associated with biodeposition by the American oyster Crassostrea virginica (Gmelin). PhD dissertation, University of Maryland, Cambridge

Jordan SJ, Coakley JM (2004) Long-term projections of eastern oyster populations under various management scenarios. J Shellfish Res 23:63-72

Jordan SJ, Greenhawk KN, McCollough CB, Vanisko J, Homer ML (2002) Oyster biomass, abundance, and harvest in northern Chesapeake Bay: trends and forecasts. J Shellfish Res 21:733-741
Jordan TE, Whigham DF, Hofmockel KH, Pittek MA (2003) Nutrient and sediment removal by a restored wetland receiving agricultural runoff. J Environ Qual 32:1534-1547

Kemp WM, Boynton WR, Stevenson JC, Twilley RR, Means JC (1983) The decline of submerged vascular plants in upper Chesapeake Bay: summary of results concerning possible causes. Mar Technol Soc J 17:78-89

Kemp WM, Boynton WR, Adolf JE, Boesch DF and 13 others (2005) Eutrophication of Chesapeake Bay: historical trends and ecological interactions. Mar Ecol Prog Ser 303:1-29

Lacouture RV, Wagoner BB, Nealley E, Sellner KG, Summers $R$ (1990) Dynamics of the microbial food web in the Patuxent River: autotrophic picoplankton. In: New perspectives in the Chesapeake system: a research and management partnership. Chesapeake Research Consortium, Baltimore, MD, p 297-307

Langdon CJ, Newell RIE (1990) Utilization of detritus and bacteria as food sources by two bivalve suspension-feeders, the oyster Crassostrea virginica and the mussel Geukensia demissa. Mar Ecol Prog Ser 58:299-310

Lenihan HS (1999) Physical-biological coupling on oyster reefs: how habitat structure influences individual performance. Ecol Monogr 69:251-275

Loosanoff VL (1962) Effects of turbidity on some larval and adult bivalves. Proc Gulf Caribb Fish Inst 14:80-95

Lund EJ (1957) Self silting by the oyster and its significance for sedimentation geology. Publ Inst Mar Sci Univ Texas 4: 320-327

Mackenzie CLJ, Burrell VG, Rosenfield A, Hobart WL (1997) The history, present condition, and future of the molluscan fisheries of North America and Europe, Vol 1. Atlantic and Gulf Coasts. NOAA Tech Rep NMFS 127

Malone TC (1992) Effects of water column processes on dissolved oxygen, nutrients, phytoplankton, and zooplankton. In: Smith DE, Leffler M, Mackiernan G (eds) Oxygen dynamics in the Chesapeake Bay. Maryland Sea Grant College, College Park, MD, p 61-112

McCay DPF, Peterson CH, DeAlteris JT, Catena J (2003) Restoration that targets function as opposed to structure: replacing lost bivalve production and filtration. Mar Ecol Prog Ser 264:197-212

Nakamura Y, Kerciku F (2000) Effects of filter-feeding bivalves on the distribution of water quality and nutrient cycling in a eutrophic coastal lagoon. J Mar Syst 26:209-221

Neumann T, Schemewski G (2005) An ecological model evaluation of two nutrient abatement strategies for the Baltic Sea. J Mar Syst 56:195-206

Newell RIE (1988) Ecological changes in Chesapeake Bay: Are they the result of overharvesting the American oyster, Crassostrea virginica? In: Lynch MP, Krome EC (eds) Understanding the estuary: advances in Chesapeake Bay research. Chesapeake Research Consortium, Gloucester Point, VA, p 536-546

Newell RIE (2004) Ecosystem influences of natural and cultivated populations of suspension-feeding bivalve molluscs: a review. J Shellfish Res 23:51-61

Newell RIE, Koch EW (2004) Modeling seagrass density and distribution in response to changes in turbidity stemming from bivalve filtration and seagrass sediment stabilization. Estuaries 27:793-806

Newell RIE, Langdon CJ (1996) Mechanisms and physiology of larval and adult feeding. In: Kennedy VS, Newell RIE, Eble AF (eds) The eastern oyster Crassostrea virginica. Maryland Sea Grant College, College Park, MD, p 185-230

Newell RIE, Ott J (1998) Macrobenthic communities and eutrophication. In: Malone TC, Malej A, Harding LW, Smodlaka N, Turner RE (eds) Ecosystems at the land-sea 
margin: drainage basin to coastal sea. Coast Estuar Stud 55: 265-293

Newell RIE, Fisher TR, Holyoke RR, Cornwell JC (2005) Influence of eastern oysters on nitrogen and phosphorus regeneration in Chesapeake Bay, USA. In: Dame R, Olenin S (eds) The comparative roles of suspension feeders in ecosystems. NATO Science Series: IV Earth and Environmental Sciences, Vol 47. Springer, Netherlands, p 93-120

Nixon SW (1995) Coastal marine eutrophication: a definition, social causes, and future concerns. Ophelia 41:199-219

NRC (National Research Council) (2004) Nonnative oysters in Chesapeake Bay. The National Academies Press, Washington DC

Officer CB, Smayda TJ, Mann R (1982) Benthic filter feeding, a natural eutrophication control. Mar Ecol Prog Ser 9: 203-210

Olsson P, Graneli E, Carlsson P, Abreu P (1992) Structuring of a postspring phytoplankton community by manipulation of trophic interactions. J Exp Mar Biol Ecol 158:249-266

Orth RJ, Moore KA (1983) Chesapeake Bay - an unprecedented decline in submerged aquatic vegetation. Science 222:51-53

Orth RJ, Batiuk RA, Bergstrom PW, Moore KA (2002) A perspective on two decades of policies and regulations influencing the protection and restoration of submerged aquatic vegetation in Chesapeake Bay, USA. Bull Mar Sci 71: 1391-1403

Pomeroy LR, D'Elia CF, Schaffner LC (2006) Limits to topdown control of phytoplankton in Chesapeake Bay. Mar Ecol Prog Ser 325:301-309

Prins TC, Small AC, Dame RF (1998) A review of the feedbacks between grazing and ecosystem processes. Aquat Ecol 31:349-359

Ray RT, Haas LW, Sieracki ME (1989) Autotrophic picoplankton dynamics in a Chesapeake Bay sub-estuary. Mar Ecol Prog Ser 52:273-285

Rothschild BJ, Ault JS, Goulletquer P, Heral M (1994) Decline

Editorial responsibility: Kenneth Heck Jr. (Contributing Editor), Dauphin Island, Alabama, USA in the Chesapeake Bay oyster population: a century of habitat destruction and overfishing. Mar Ecol Prog Ser 111: 29-39

Shumway SE (1996) Natural environmental factors. In: Kennedy VS, Newell RIE (eds) The eastern oyster, Crassostrea virginica. Maryland Sea Grant, Annapolis, MD, p 467-513

Smith GF, Greenhawk KN, Bruce DG, Roach EB, Jordan SJ (2001) A digital presentation of the Maryland oyster habitat and associated bottom types in the Chesapeake Bay (1974-1983). J Shellfish Res 20:197-206

Smith GF, Roach EB, Bruce DG (2003) The location, composition, and origin of oyster bars in mesohaline Chesapeake Bay. Estuar Coast Shelf Sci 56:391-409

Soniat TM, Finelli CM, Ruiz JT (2004) Vertical structure and predator refuge mediate oyster reef development and community dynamics. J Exp Mar Biol Ecol 310:163-182

Souchu P, Vaquer A, Collos Y, Landrein S, Deslous-Paoli J, Bibent B (2001) Influence of shellfish farming activities on the biogeochemical composition of the water column in Thau lagoon. Mar Ecol Prog Ser 218:141-152

Southworth M, Harding JM, Mann R (2005) The status of Virginia's public oyster resource 2004. Virginia Institute of Marine Science, Gloucester Point, VA

Suding KN, Gross KL, Houseman GR (2004) Alternative states and positive feedbacks in restoration ecology. Trends Ecol Evol 19:46-53

Ulanowicz RE, Tuttle JH (1992) The trophic consequences of oyster stock rehabilitation in Chesapeake Bay. Estuaries 15: 298-306

Yates C (1911) Survey of oyster bars by county of the State of Maryland. Department of Commerce and Labor, Coast and Geodetic Survey, Washington DC

Youngsik S, Wetzel RL, Anderson IC (2000) Seasonal variations of size-fractionated phytoplankton along the salinity gradient in the York River estuary, Virginia (USA). J Plankton Res 22:1945-1960

Submitted: December 16, 2005; Accepted: September 8, 2006 Proofs received from author(s): April 5, 2007 